\title{
Incidence and trend of blocking action situations on the temperature and precipitation in Argentina
}

\author{
ADELIA P. ALESSANDRO \\ Departamento de Ciencias de la Atmósfera y los Océanos, Facultad de Ciencias Exactas y Naturales, Universidad \\ de Buenos Aires, Intendente Güiraldes 2160, Ciudad Universitaria, C1428EGA Buenos Aires, Argentina \\ Corresponding author; e-mail: perlaalessandro@yahoo.com.ar
}

Received November 21, 2013; accepted January 13, 2014

\begin{abstract}
RESUMEN
Se determinan las frecuencias y tendencias de situaciones de acción bloqueante (Bs, por sus siglas en inglés) en el sur de Sudamérica durante el periodo 1960-2011, calculadas en 100 (B100), 70 (B70) y 40 (B40) de longitud oeste. Se estudia además el efecto que estas situaciones ejercen sobre la temperatura y la precipitación. La distribución de la frecuencia de B100, B70 y B40 presenta un máximo en primavera y un mínimo en verano; las tendencias son positivas en verano y otoño y negativas en invierno y primavera. A excepción del verano, las precipitaciones son mayores a las normales cuando los Bs se producen en ambas longitudes. Al norte de aproximadamente $38^{\circ} \mathrm{S}, \mathrm{B} 70$ determina anomalías de temperatura $(\Delta \mathrm{T})$ negativas sobre todo el país durante las cuatro estaciones del año y B40 lo hace en primavera y verano. Al sur de aproximadamente $38^{\circ} \mathrm{S}, \mathrm{B} 100$ produce $\Delta \mathrm{T}$ negativas. Las frecuencias y cantidades de precipitación son mayores en primavera. En otoño (verano) la zona afectada por mayores precipitaciones se reduce a la zona superior norte (inferior sur). De acuerdo con los signos de las tendencias de Bs y de los valores asociados de temperatura y precipitación, se puede inferir que estas situaciones podrían haber contribuido a la variación de ambas variables durante el periodo 1960-2011
\end{abstract}

\begin{abstract}
In southern South America and for the period 1960-2011, frequencies and trends of seasonal blocking situations (Bs) determined at 100, 70 and $40^{\circ} \mathrm{W}$ (B100, B70 and B40), respectively are estimated. The effect of such situations on temperature and precipitation is also analyzed. The distribution of occurrences of B100, B70 and B40 peaks in spring and has minimum values in summer; trends are positive in summer and fall and negative in winter and spring. To the north of approximately $38^{\circ} \mathrm{S}, \mathrm{B} 70$ determines negative temperature anomalies $(\Delta \mathrm{T})$ over the entire country during the four seasons and B40 in spring and summer. Except for summer, rainfall is greater than normal when Bs occur at both longitudes. To the south of approximately $38^{\circ}$ $\mathrm{S}, \mathrm{B} 100$ give place to negative $\Delta \mathrm{T}$. The frequencies and amounts of precipitation are greater in spring. This area is limited to the northernmost northern (southernmost southern) area in fall (summer). According to the signs of the trends of the Bs and to the associated values of temperature and precipitation, the way in which they may have contributed to the change in both variables during 1960-2011 is inferred.
\end{abstract}

Keywords: Indices, circulation change, temperature, precipitation.

\section{Introduction}

A blocking pattern exists when systems do not progress within the latitude belt of the baroclinic westerlies. The zonal movement of short waves is effectively halted, as the zonal current vanishes, and hence vorticity advection, the major mechanism by which upper level systems move, becomes negligible. Blocking situations pose a major threat for many people, especially those living near upper-level cyclones or near upper-level anticyclone, since the 
persistent circulation around these systems influence cloudiness, precipitation and temperature.

Blocking situations in the southern hemisphere (SH) were statistically studied first by van Loon (1956) and Taljaard (1972). Subsequently, during the 1980s several authors such as Trenberth and Swanson (1983), Trenberth and Mo (1985), and Trenberth (1986), among others, shed light on the statistical and dynamical knowledge of blocking events occurrence. Noar (1983) applied a numerical forecast to analyze the start and end of a blocking event in Australia during winter 1983 that produced a severe drought and economic damages. Mo (1983) studied the relationship between blocking events and Rossby long waves as well as their amplitudes in the $\mathrm{SH}$.

Some authors, like Mo (1983) and Trenberth (1986) found that the duration of blocking events or large anomalies are less persistent and of lower amplitude in the SH than in the NH. Trenberth attributed this to the presence of the generally stronger westerlies throughout the troposphere at middle to high latitudes of the $\mathrm{SH}$.

Though Tibaldi et al. (1994) found that the number of blockings near $70^{\circ} \mathrm{W}$ is low, other authors point out that the SW of South America is a region with an important presence of these systems. Moreover, in this work $70^{\circ} \mathrm{W}$ was selected because the blocking situations at that latitude are the best correlated with temperature and precipitation over Argentina in an extended territory, as shown by Alessandro (2003 b).

Results from Trenberth and Mo (1985) showed that a blocking frequency maximum is found in the $45-60^{\circ} \mathrm{S}$ band over southeastern New Zealand followed by a second frequency peak in the southeast of South America and a minor peak over the Indian Ocean. Some years later, Sinclair (1996) and Mo and Higgins (1997), confirmed the same maxima found and obtained a new area in the southern Pacific, west of South America. Most studies mentioned, found that persistent anomalies are located southeast of New Zealand. This is a region where the climatological split in the jets favors the formation of blocks (Kiladis and Mo, 1998).

Some authors have considered different numbers of consecutive days to define a blocking situation. Much of the pioneering observational work on blocking was done by Rex (1950). For the Northern Hemisphere, he considered as a blocking case that in which the high-pressure system remains almost stationary for at least 10 days. Other authors like Mo (1983) considered seven or more consecutive days, and Trenberth (1986) used five or more days.

Some researchers analyzed the relationship between blocking events and temperature and precipitation for brief periods. Berbery and Lozano (1991) defined a blocking event as those situations where a positive anomaly larger than $150 \mathrm{hPa}$ at $200 \mathrm{hPa}$ persists at least for five days, in both the southern Pacific and southern Atlantic oceans. They also related these events to minimum temperature and precipitation in Argentina from April to June between 1980 and 1986. Positive persistent anomalies in the Atlantic were associated with positive precipitation anomalies to the south of $30^{\circ} \mathrm{S}$, negative and more irregularly distributed precipitation anomalies to the north of that latitude, positive minimum temperature anomalies in central Argentina, and negative minimum temperature anomalies over northeastern Argentina. A blocking in the Pacific was associated with negative minimum temperature anomalies and positive precipitation anomalies in Patagonia and negative precipitation anomalies over central and northern Argentina. The Argentinean Patagonia is the region that extends from the Andes mountain range to the Atlantic Ocean and from the Mendoza state of Malargue ( $\left.35^{\circ} 17^{\prime} \mathrm{S}\right)$ to the Colorado River (approximately $38^{\circ} 30^{\prime} \mathrm{S}$ ) on the north and to the waters that are located to the south of Cape Horn in the Drake Passage to the south.

In particular, Marques and Rao (1999) analyzed the influence on precipitation of a blocking event occurred from 29 July to 14 August 1986 in South America. They found that precipitation increased to the north of the blocking high but decreased to the south of it. The increment was associated to the northward deflection of migratory lows to the north of the blocking area whereas the decrease was associated to the subsidence effect produced by the blocking high. To the west of South America Rutllant and Fuenzalida (1991) studied the frequency of blocking events and its relationship with the increased precipitation in central Chile.

For the 1979-1995 period, Kayano (1999) found that positive pressure anomalies between 130 and $120^{\circ} \mathrm{W}$ in the South Pacific, with a persistence of more than seven days, produced negative temperature anomalies south of $46^{\circ} \mathrm{S}$ in Argentina during the austral winter and south of $35^{\circ} \mathrm{S}$ during the austral summer. 
Some authors, like Mo (1983) and Trenberth and Mo (1985) found that the duration of blocking events or the large anomalies are less persistent and of lower amplitude in the SH than in the NH. Trenberth attributed this to the presence of the generally stronger westerlies throughout the troposphere at middle to high latitudes of the $\mathrm{SH}$.

Van Loon (1956), Lejenas and Okland (1983), Lejenas (1984), Kidson (1986), Kayano and Kousky (1989), among others, in search to simplify the interpretation of different atmospheric states used indexes to detect blocking events and determined thresholds to differentiate each kind of phenomenon. Recently Kreienkamp et al. (2010) used a circulation index to locate blockings between 40 and $60^{\circ} \mathrm{N}$ and between $30^{\circ} \mathrm{W}$ and $30^{\circ} \mathrm{E}$, which has relevance for mid-latitudes.

Some of the indexes most commonly used to represent atmospheric states in middle latitudes are zonal indexes calculated at $1000 \mathrm{hPa}$ and $500 \mathrm{hPa}$ as the difference between two latitudes, one corresponding to lower latitudes and the other to higher latitudes. Kayano and Kousky (1989) used, as did the Australian Bureau of Meteorology before them, indexes composed by the zonal wind component.

For the reasons previously explained, the author of this work performed several studies in the southern end of South America over both the southern Pacific and southern Atlantic oceans in the period from December 1989 to December 1998 (Alessandro 2003a, 2003b, 2005a, 2005b, 2011).

In the first paper (Alessandro 2003a), the zonal index I (see definition in section 2) at $500 \mathrm{hPa}$ was used, and a blocking action situation (Bs) was defined if this index remained positive during at least five consecutive days. The temporal distribution and intensity of I were analyzed in addition to the sequences of different days on which I $>0$. Next, Alessandro (2003b) correlated the I indices recorded in 40, 70 and $100^{\circ} \mathrm{W}$ (I40, I70 and I100) with the temperature and precipitation values. For I70, this correlation was significant at the 95\% level, and covered all of Argentina with the exception of the region south of the Argentinean Patagonia; for I40, the correlation was significant for the region that was north of $40^{\circ} \mathrm{S}$, and for I100, it was only significant in Patagonia.

The author analyzed the influence of the positive I indices on temperature and precipitation without considering the season of the year. Precipitation was calculated through the relationship between the number of rainy days when I was positive and the days on which I was negative. The greater frequencies of days with precipitation were detected in almost all of the country when the indexes were calculated at $70^{\circ} \mathrm{W}$; the frequencies were smaller to the north of $32^{\circ} \mathrm{S}$ when evaluated with the index at $40^{\circ} \mathrm{W}$, and they were greater in Patagonia when I was calculated at $100^{\circ} \mathrm{W}$. Regarding temperature, the author calculated the mean annual anomalies that were produced by all of the blocking situations. Based on previous calculations, the probability of obtaining temperatures below the mean values at the moment that B40 (B70) was produced was 60 to $80 \%$ for the region north of $32^{\circ} \mathrm{S}$ (south of $32^{\circ} \mathrm{S}$ ). For B100, the probability of obtaining negative anomalies in Patagonia varied between 53 and $78 \%$.

For the same period and without discriminating by the season of the year, Alessandro (2005a) analyzed the influence of the simultaneous blocking situations in the south Pacific and south Atlantic on both variables

Because B70 had a greater influence on both variables across the Argentinean territory, Alessandro (2005b), in a later study analyzed the differences that were caused on temperature and precipitation under the same aforementioned conditions when blockings occurred to the left or the right of the target longitude.

Zonda is an intense wind characterized by its extreme dryness and high temperature, which is acquired when the air descends down the eastern side of the Andes mountain slope. It has strong effect on the regions located at the foot of the mountain between the provinces of Neuquen $\left(40^{\circ} \mathrm{S}\right)$ and Jujuy $\left(22^{\circ} \mathrm{S}\right)$. At latitudes higher than $40^{\circ} \mathrm{S}$, where the largest number of blockings occur and where the Fohen (Zonda) effect is weak given the lower height of the Andes, this effect has not been discriminated. Up to the present there are no references available of papers analyzing the incidence of the Zonda effect on both variables in the mentioned latitudes.

This work intends to analyze the seasonal variability of the frequencies of blocking action situations at 100,70 and $40^{\circ} \mathrm{W}$ between 1960 and 2011. The seasonal distribution of these situations and their influence on the seasonal values of temperature and precipitation will be studied.

Seasonal trends of the blocking situations will be analyzed, and through them and the seasonal values 
of precipitation and temperature associated with blocking situations, an estimate of the effect that these situations could have exerted on both variables during the course of this period will be performed.

\section{Data and methods}

Daily surface temperatures at 12 UTC (taken at the meteorological shelter) and daily rainfall data from 43 weather stations were provided by the National Meteorological Service (SMN). Daily 500 and $1000 \mathrm{hPa}$ geopotential heights at $12 \mathrm{Z}$ as well as graphical outputs of geopotential heights were obtained from the reanalyses of the National Center of Environmental Prediction (NCEP) over a $2.5 \times 2.5^{\circ}$ grid. All data cover the period 1960- 2011.

The I index used in the present work, and in previous works of the author, distinguishes blocking action situations. I, calculated at three selected longitudes $\left(100,70\right.$ and $\left.40^{\circ} \mathrm{W}\right)$, is defined as follows:

$I=U\left(30^{\circ} \mathrm{S}\right)+U\left(60^{\circ} \mathrm{S}\right)-2 U\left(45^{\circ} \mathrm{S}\right)$

where $U$ is the zonal wind component $(\mathrm{m} / \mathrm{s})$ at $12 \mathrm{Z}$ for $500 \mathrm{hPa}$.

In the mean zonal wind field it is observed that the westerlies are most intense near $45^{\circ} \mathrm{S}$ (see Annex 1), and therefore $\mathrm{I}<0$. However, it should be noticed that $45^{\circ}$ is not always the middle point, since whenever indices are used, approximations are introduced. Nonetheless, indices provide very useful information and are specially used where meteorological weather stations are not available. When the zonal component at $45^{\circ}$ $\mathrm{S}$ is abnormally weak, then I $>0$. If during more than nine consecutive days I $>0$, then a persistent blocking action situation is considered to be taking place.

The adopted I index detects a greater number of blocking action situations (Bs) than blocking situations (B) defined for other authors, since the Bs determined by the permanence of a weak ridge, are also included in the frequency of B.

First, the temporal distribution of the Bs during the selected period must be determined, therefore the monthly and seasonal histograms are calculated for each of the three longitudes. In each case the persistent Bs are then discriminated.

To examine the temporal variation of the I index, the linear seasonal trends are obtained for the 46-year period studied. Magnitudes are analyzed using the Mann-Kendall test (Brooks and Carruthers, 1953) and the significance of the slope of the regression line is tested at the $95 \%$ level.

To test the signs of trends, the seasonal anomalies fields of geopotential heights at $500 \mathrm{hPa}$ of the oldest (1960-1980) and most recent (1991-2011) periods are compared.

To evaluate the influence of the Bs on temperature and precipitation, the corresponding seasonal geopotential height anomaly fields at 500 and $1000 \mathrm{hPa}$ are determined, i.e. for each case the geopotential height fields of the days with blocking events in a season are averaged and subtracted from the mean seasonal geopotential field.

For the reasons stated in the introduction, the seasonal values of temperature and precipitation corresponding to (a) B40 over Argentina north of $38^{\circ} \mathrm{S}$, (b) B100 south of $38^{\circ} \mathrm{S}$, and (c) B70 for all of Argentina, are determined and displayed.

Temperature is evaluated through its anomalies $(\Delta \mathrm{T})$ calculated with respect to the 1960-2011 seasonal mean. The mean seasonal $\Delta \mathrm{T}$ produced for the Bs are calculated. To determine whether the seasonal mean of the sample composed of the $\Delta \mathrm{T}$ produced by blocking action situations is significantly different from the seasonal mean composed of the $\Delta \mathrm{T}$ of the rest of the series, Student's $t$-test is applied to each of the meteorological stations.

$T=(X b-X n b) / S(1 / N b+1 / N n b)^{1 / 2}$

where $S^{2}=\left(N b S b^{2}+N m b S n b^{2} / N b+N n b\right)$

$X b$ is the mean of the seasonal temperature anomalies of the Bs days, $X n b$ is the mean of the seasonal temperature anomalies of the rest of days in the series, $\mathrm{Nb}$ and $\mathrm{Nnb}$ are the corresponding numbers of cases, and $S b$ and $S n b$ are their variances. This process was repeated for each season of the year and for each of the selected longitudes.

To analyze the precipitation associated with the Bs, two precipitation relations are calculated: $R 1$ and $R 2$, where $R 1=r 1 / r 2$ and $R 2=r f 1 / r f 2$, where $r 1$ is the ratio between the amount of precipitation accumulated in the days when the Bs are produced in a given season of the year and the number of days with a blocking action in that season of the year, and $r 2$ is the relationship between the amount of the accumulated precipitation in the same season of the year that was selected in $r 1$ and the total amount of days of that season of the year. 

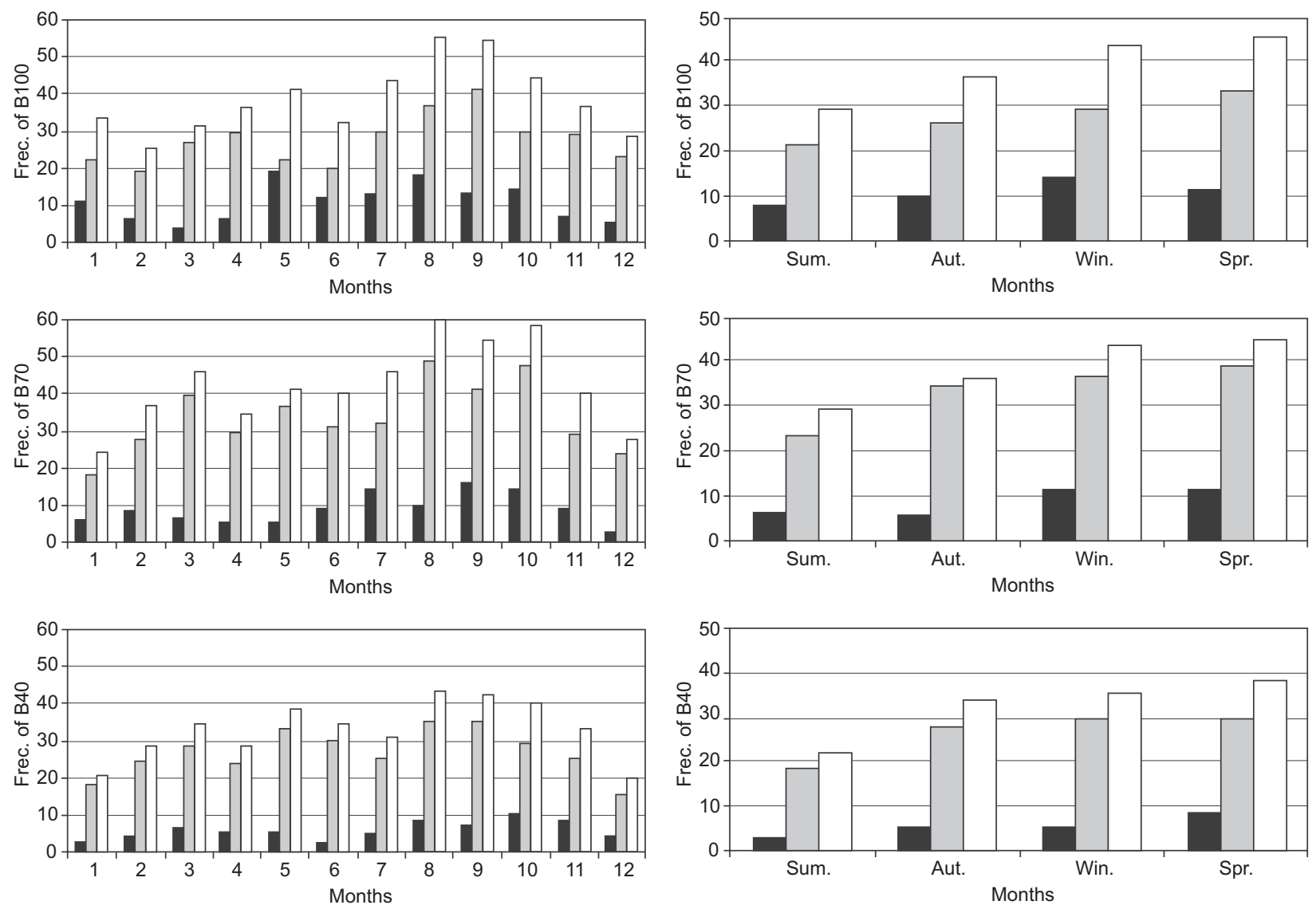

Persistant $\square$ Non-persistant $\square$ All

Fig. 1. Left-panel: monthly frequencies of B100, B70 and B40. Right- panel: seasonal frequencies for B100, B70 and B40.

In this manner, if $R 1>1$, it indicates that the mean accumulated precipitation during the $\mathrm{Bs}$ is greater than the mean accumulated precipitation in the season considered. The frequency of rainy days $(r f 1$ and $r f 2)$ is dealt with in a similar way, and $R 2$ is obtained for each season of the year and at each meteorological station.

According to the values obtained from both variables during the Bs and considering the signs of the linear seasonal trends of the Bs in the 19602011 period, an evaluation of the incidence that the blocking actions could have exerted on the temperature and the seasonal precipitation of that period is performed.

\section{Results and discussion}

\subsection{Distribution of the Bs}

Figure 1 shows the frequencies of blocking actions lasting for five to nine days (grey), and for 10 days or more (black) as well as the sum of both (squares). The month of August shows the greatest frequency of Bs in the three longitudes, although it is very similar to September at $100^{\circ} \mathrm{W}$ and to October at $70^{\circ} \mathrm{W}$. The lower frequencies are registered in February, January and December at 100, 70 and $40^{\circ} \mathrm{W}$, respectively (Fig. 1a).

The Bs that are produced at the three longitudes are less frequent in summer and are more frequent in spring, with a smaller secondary maximum in winter (Fig. 1b).

When only the $1989-1998$ period is considered (Alessandro, 2003a), the frequency distributions at the longitudes of 100 and $70^{\circ} \mathrm{W}$ changes during this shorter period show that the highest frequencies are produced in winter and a secondary maximum is produced in spring; nevertheless, the greatest frequency of Bs still occurs in both seasons and in both the short and long time period. A greater number of Bs is always observed at $70^{\circ} \mathrm{W}$; this value decreases at $100^{\circ} \mathrm{W}$, and it decreases further at $40^{\circ} \mathrm{W}$. 
Table I. Linear seasonal trends of I100, I70 and I40.

\begin{tabular}{lccc}
\hline & $100^{\circ} \mathrm{W}$ & $70^{\circ} \mathrm{W}$ & $40^{\circ} \mathrm{W}$ \\
\hline Summer & $\mathrm{y}=0.74 \mathrm{x}-17.34$ & $\mathrm{y}=0.43 \mathrm{x}-10.10$ & $\mathrm{y}=0.58 \mathrm{x}-13.58$ \\
Autumn & $\mathrm{y}=0.05 \mathrm{x}-1.41$ & $\mathbf{y}=\mathbf{0 . 2 2} \mathbf{x}-\mathbf{5 . 0 8}$ & $\mathbf{y}=\mathbf{0 . 3 3} \mathbf{- 7 . 6 9}$ \\
Winter & $\mathbf{y}=-\mathbf{0 . 6 4 x}+\mathbf{1 5 . 1 0}$ & $\mathrm{y}=-0.10 \mathrm{x}+2.39$ & $\mathrm{y}=-0.08 \mathrm{x}+1.81$ \\
Spring & $\mathrm{y}=-0.14 \mathrm{x}+3.39$ & $\mathbf{y}=-\mathbf{0 . 1 5 x}+\mathbf{0 . 5 0}$ & $\mathrm{y}=-0.10 \mathrm{x}+2.01$ \\
\hline
\end{tabular}

Significant trend equations at the $95 \%$ confidence level are in bold. $\mathrm{x}$ : time.

a)

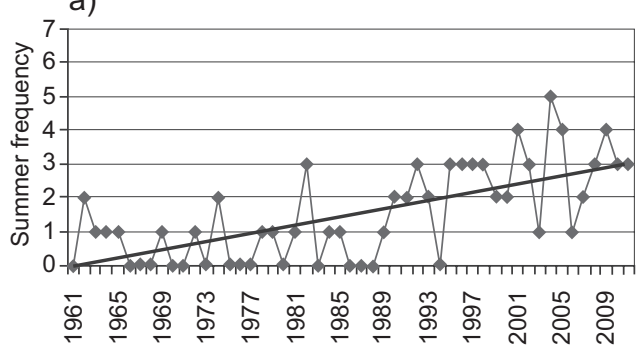

c)

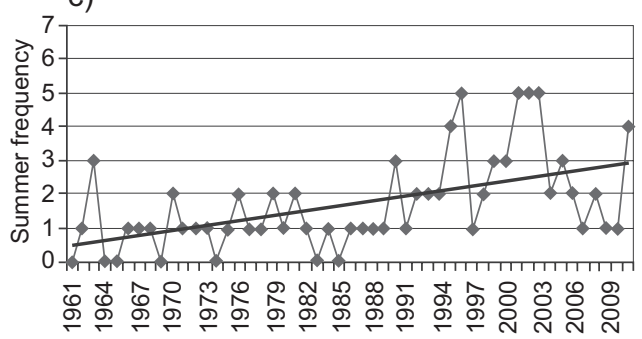

b)

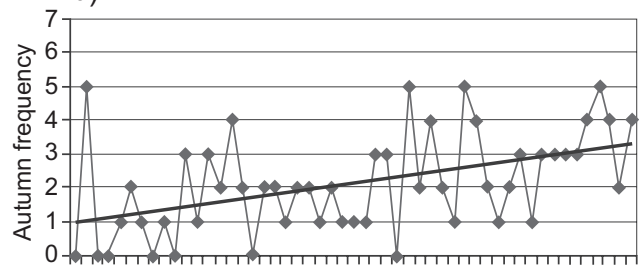

店芯

d)

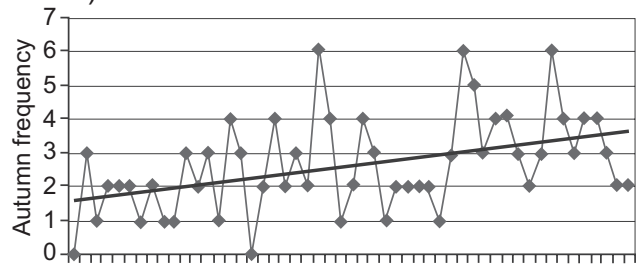

席志
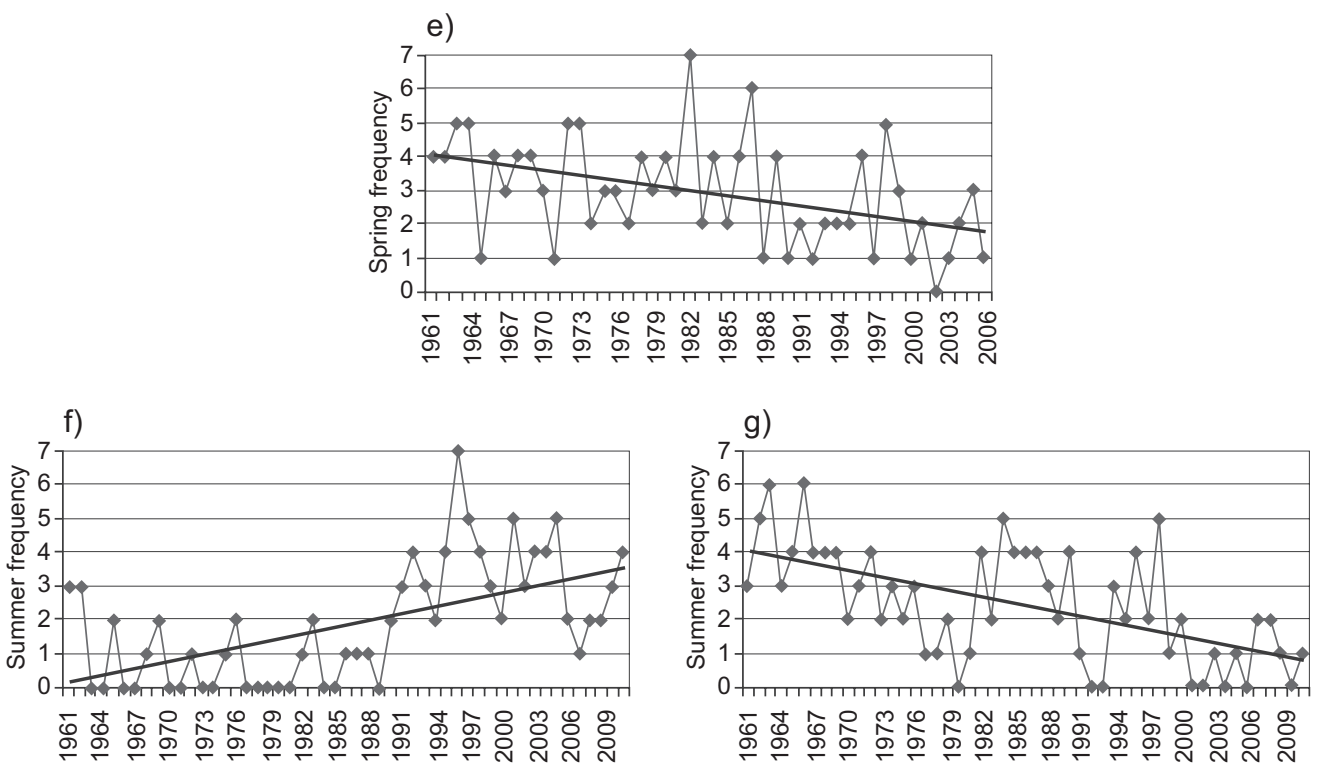

㐫志

Fig. 2. Significant monthly frequency trends of: B40 in summer (a) and autumn (b); B70 in summer (c), autumn (d) and spring (e); and B100 in summer (f) and winter (g). 

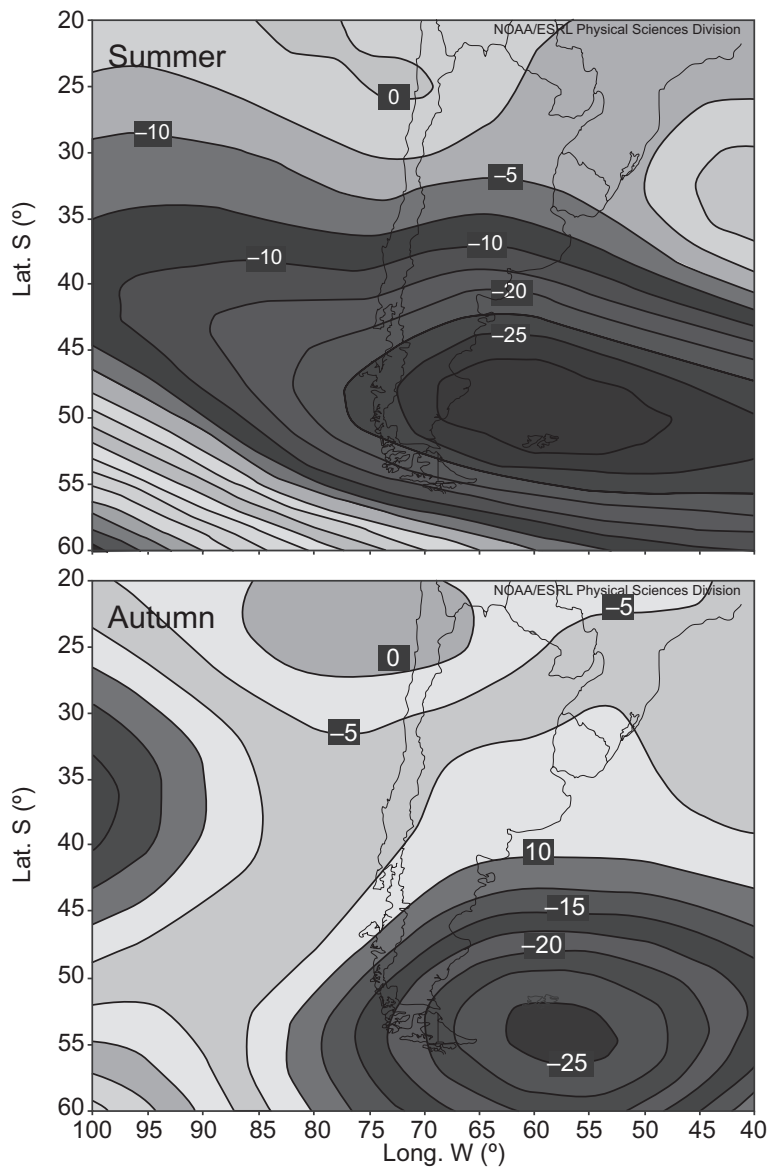

a)

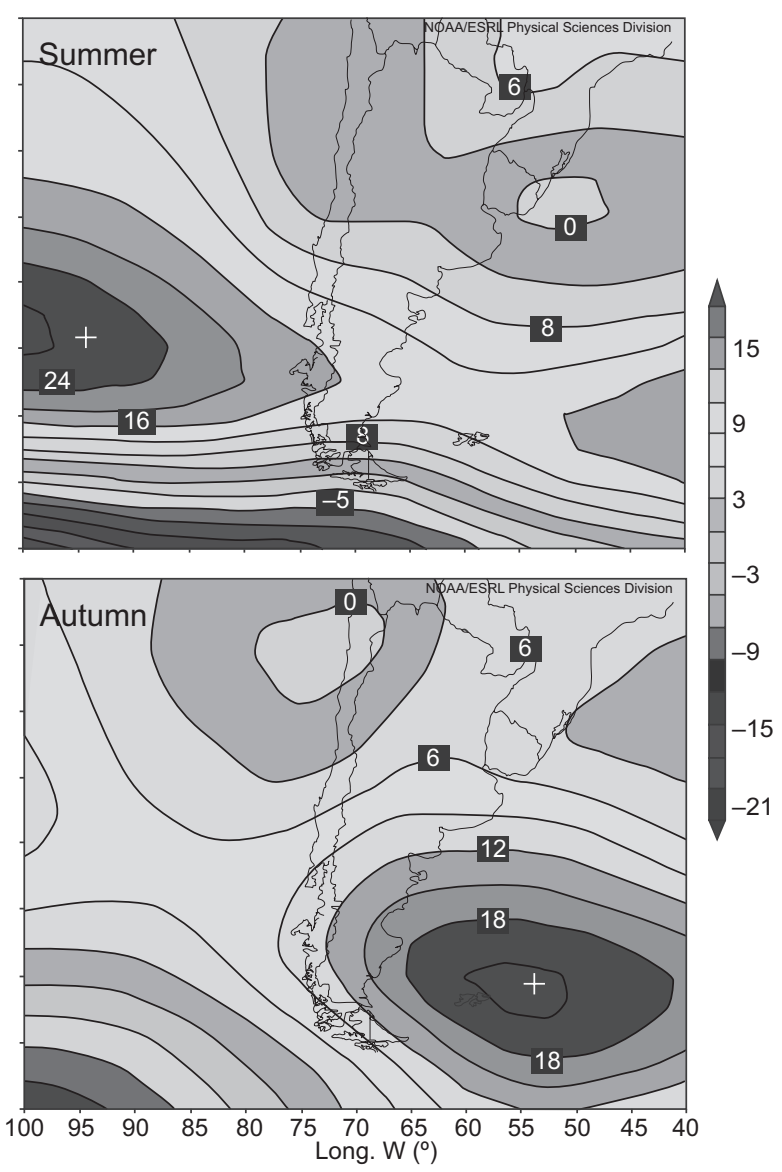

b)

Fig. 3. Seasonal anomalies of the geopotential height fields at $500 \mathrm{hPa}$ in summer and autumn during: (a) the period 1960-1979, and (b) the period 1992-2011.

As shown in Figure 1, the number of persistent blocking actions is very low with respect to the Bs that do not persist. These values are between 15 and $35 \%$ of the latter. The monthly distributions show their maximum values in May, September and October at 100,70 and $40^{\circ} \mathrm{W}$, respectively. In the same figure, it can be seen that the persistent blocking situations occurred with a greater frequency at $100^{\circ} \mathrm{W}$.

The values of the frequencies of persistent blockings vary mostly between 0 and 4 and are higher in only a few years.

It is important to point out that at $100^{\circ} \mathrm{W}$ there has always been at least one blocking situation case per year in spring. In summer, the first persistent case at $40^{\circ} \mathrm{W}$ was recorded in 1972, and the first persistent case at $70^{\circ} \mathrm{W}$ in 1973 . Something similar is observed for B70 during autumn; in other words, persisting Bs are almost inexistent during the first decade.

\subsection{Trends}

Table I shows the equations for the linear trends of the I index. Significant trend equations at 95\% level are bolded. It can be seen that the trend is positive during summer and autumn, except autumn at $100^{\circ} \mathrm{W}$, which is not significant at the $95 \%$ confidence level. A greater significance in summer at all longitudes is seen, and it is found precisely in the season where there is a reduced frequency of blocking actions. In addition to the significant values for summer, there is a significant negative trend in winter at $100^{\circ} \mathrm{W}$ and in spring at $70^{\circ} \mathrm{W}$.

The trends calculated for the Bs show the same signs and significances for the trends of I. Figure 2 shows the linear distribution of B100, B70 and B40 in the seasons with significant trends. In summer, an increase is observed in the last two decades. Prior to the last two decades, Bs were 0.70, 1.1 and 0.60 per year, and they varied from those values by 4.05, 2.70 and 2.45 at 100,70 and $40^{\circ} \mathrm{W}$, respectively. 

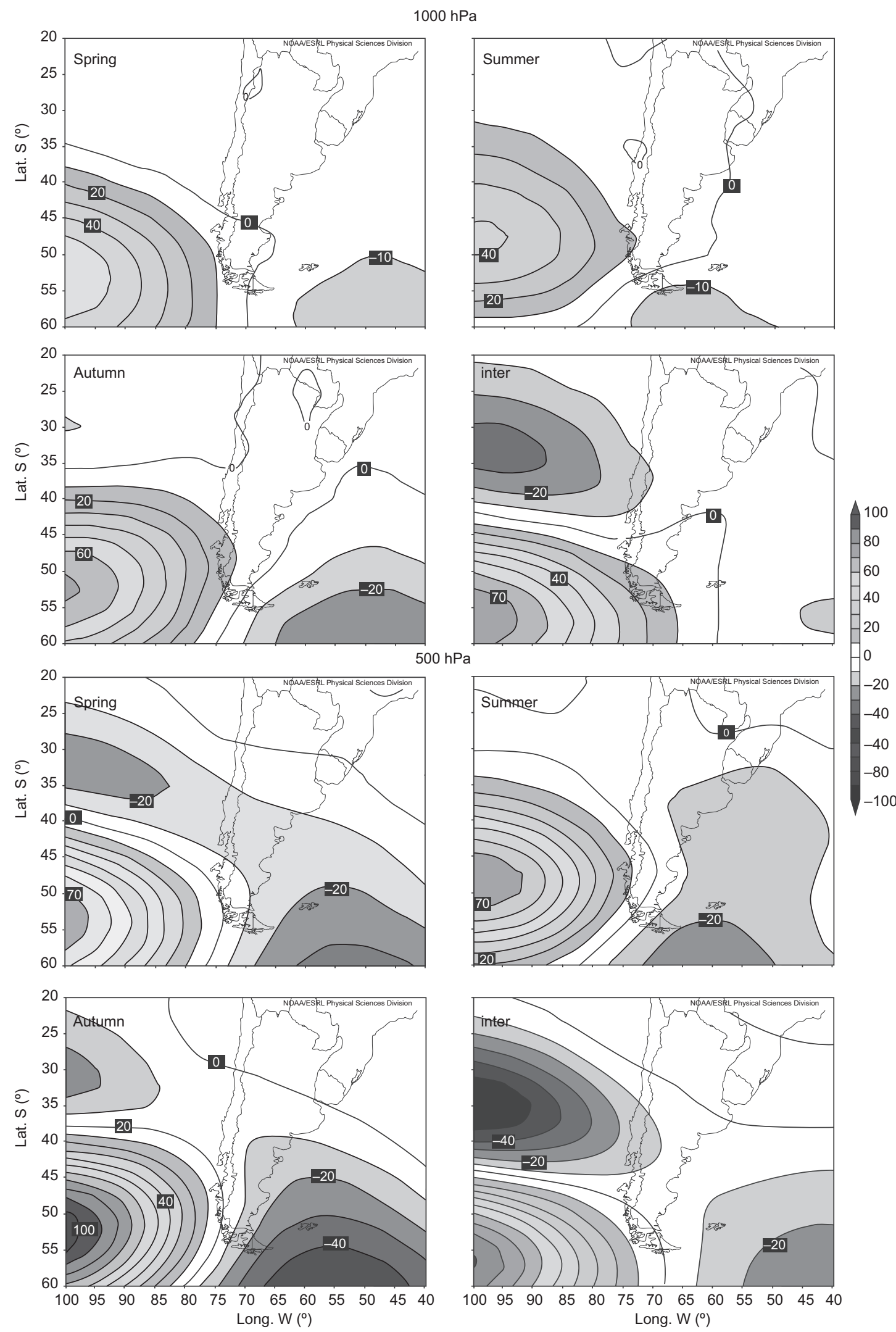

Fig. 4. Seasonal anomalies of the geopotential height fields for B100 at $1000 \mathrm{hPa}$ and $500 \mathrm{hPa}$. 
$1000 \mathrm{hPa}$
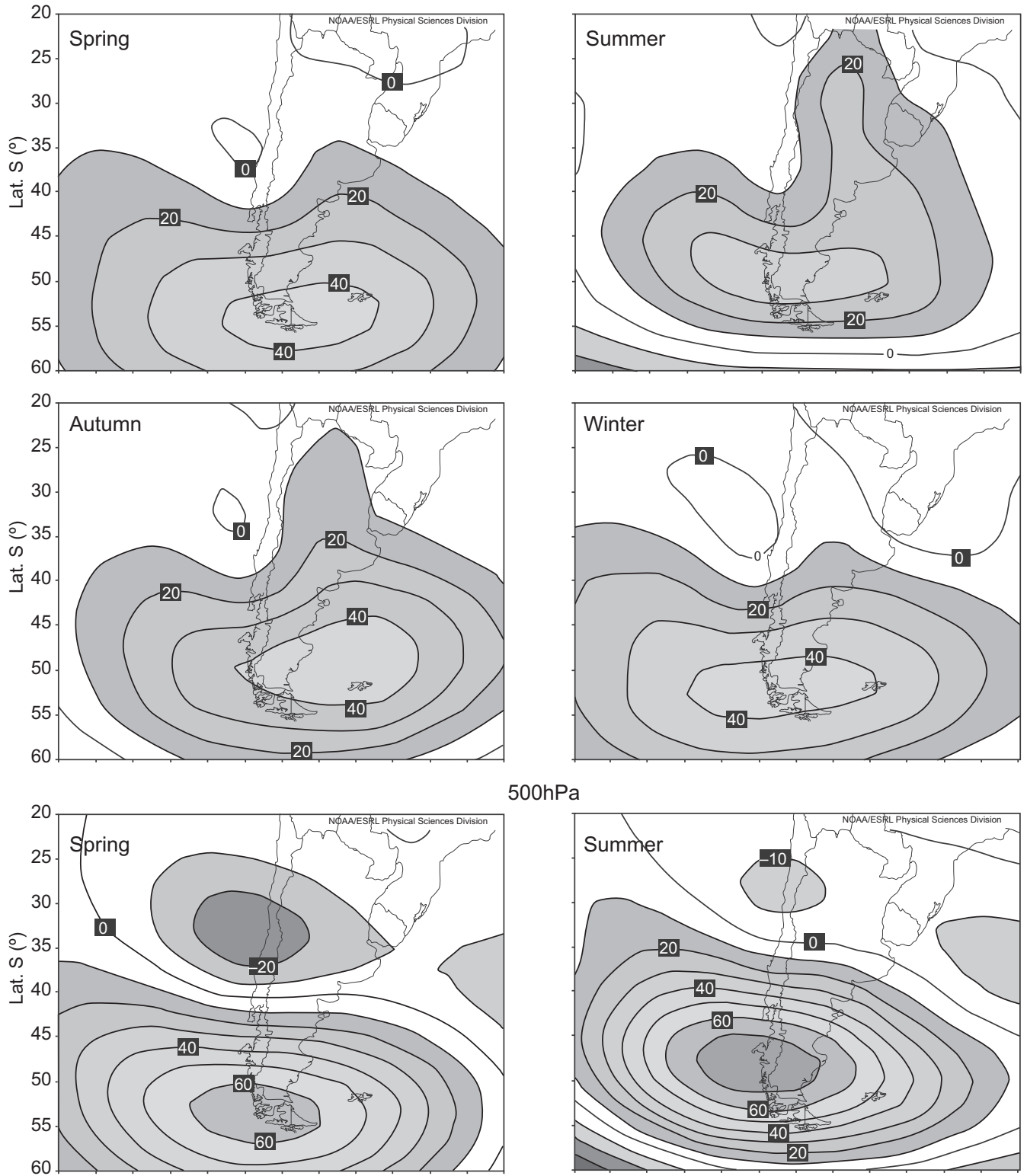

$500 \mathrm{hPa}$
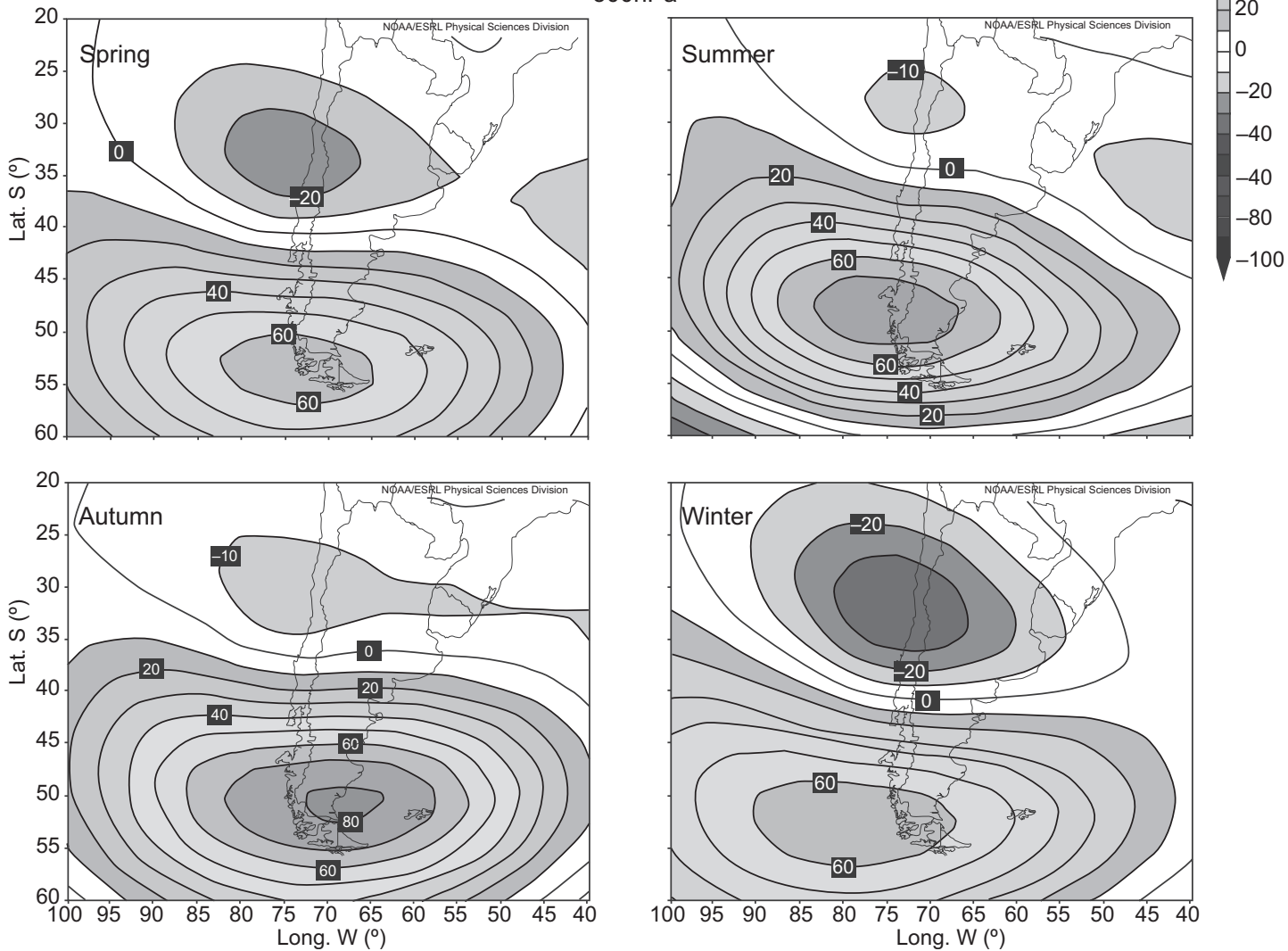

Fig. 5. Seasonal anomalies of the geopotential height fields for B70 at $1000 \mathrm{hPa}$ and $500 \mathrm{hPa}$. 
$1000 \mathrm{hPa}$
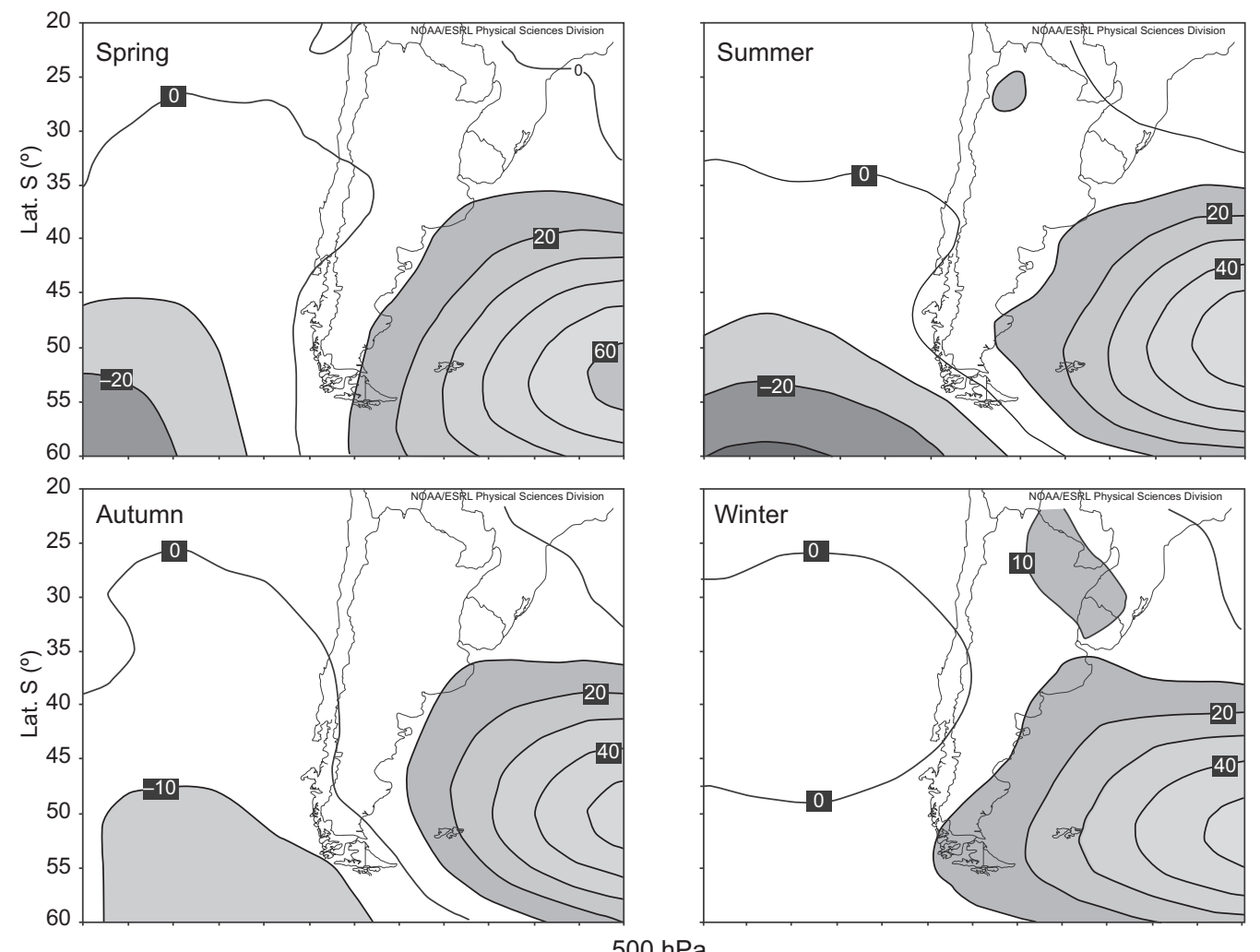

100
80
60
40
20

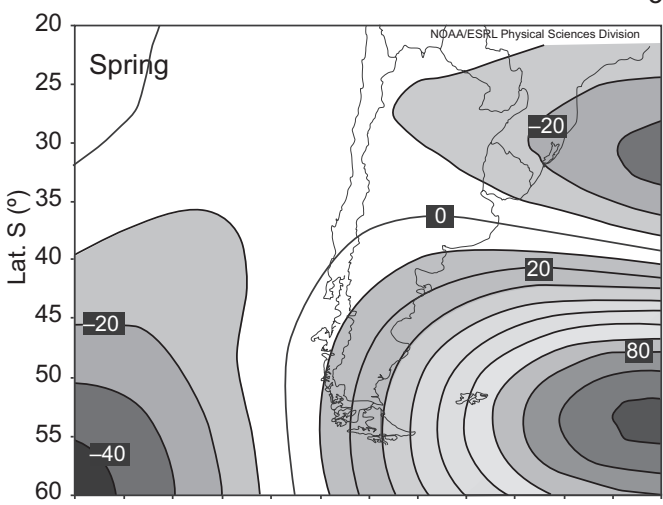

$500 \mathrm{hPa}$
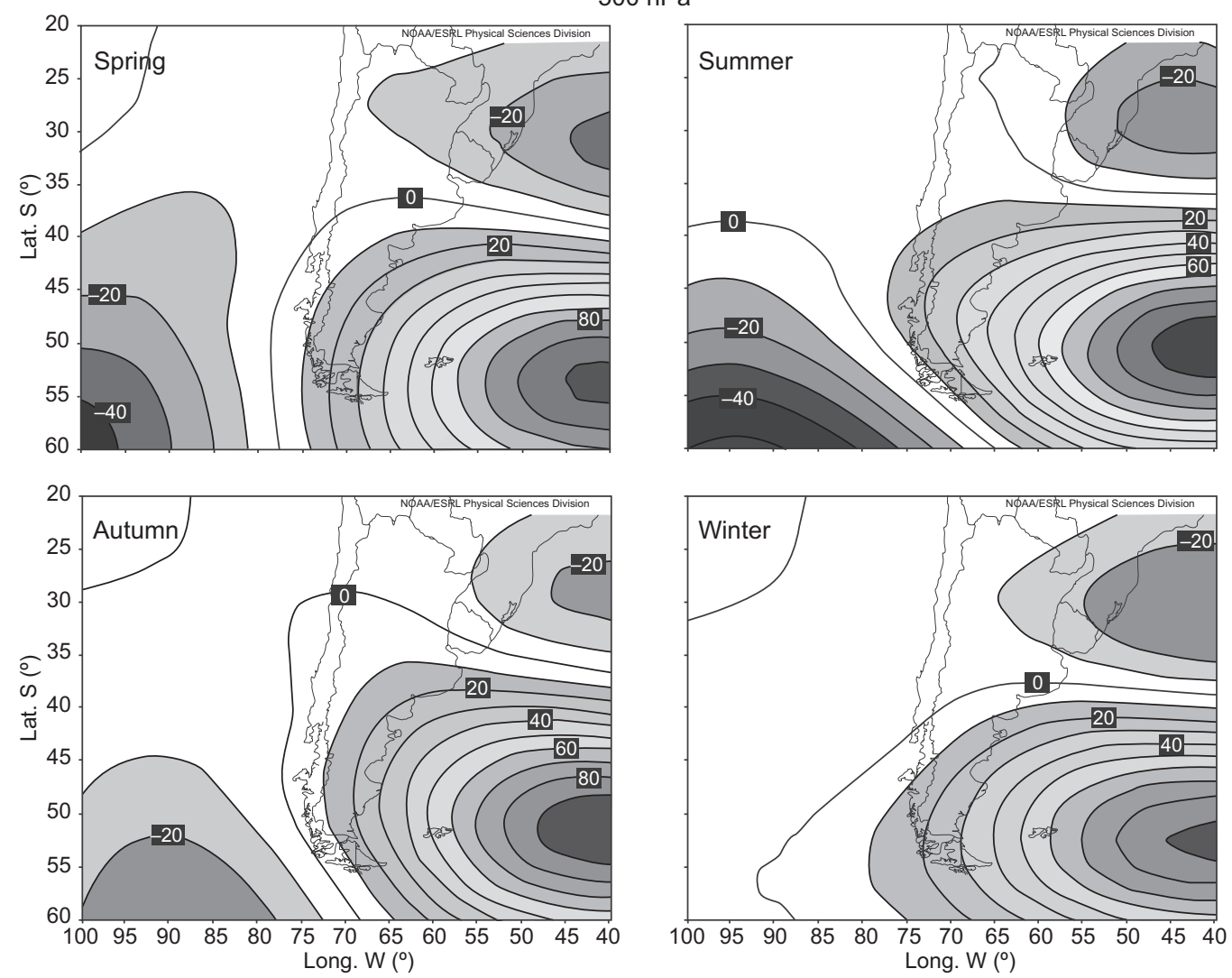

Fig. 6. Seasonal anomalies of the geopotential height fields for B40 at $1000 \mathrm{hPa}$ and $500 \mathrm{hPa}$ 
Given the trends discussed above which lead to a higher frequency of blockings, the $500 \mathrm{hPa}$ geopotential height anomaly fields for the first (1960-1979) and last (1992-2011) 20 years are calculated with respect to 1960-2011 and shown in Figure 3. For both periods only the two seasons of the year that showed the greatest significance in the three longitudes were considered. The latitudes between 30 and $60^{\circ} \mathrm{S}$ show a negative anomaly centered over the south Atlantic during the first period (a); in contrast, the second period presents positive anomalies over both oceans (b). These anomalies with opposite signs could probably be caused by the existence of a greater number of blocking actions in the last 20 years, according to the signs of the trends.

\subsection{Influence of Bs on temperature and precipitation} 3.3.1 Seasonal anomalies of the geopotential heigths fields

Figures 4-6 show the mean seasonal anomaly fields of geopotential heights at 1000 and $500 \mathrm{hPa}$, which correspond to all of the cases in which the Bs are detected at 100,70 and $40^{\circ} \mathrm{W}$, respectively. In all of the cases, a positive anomaly can be observed near $55^{\circ} \mathrm{S}$ for each of the selected longitudes.
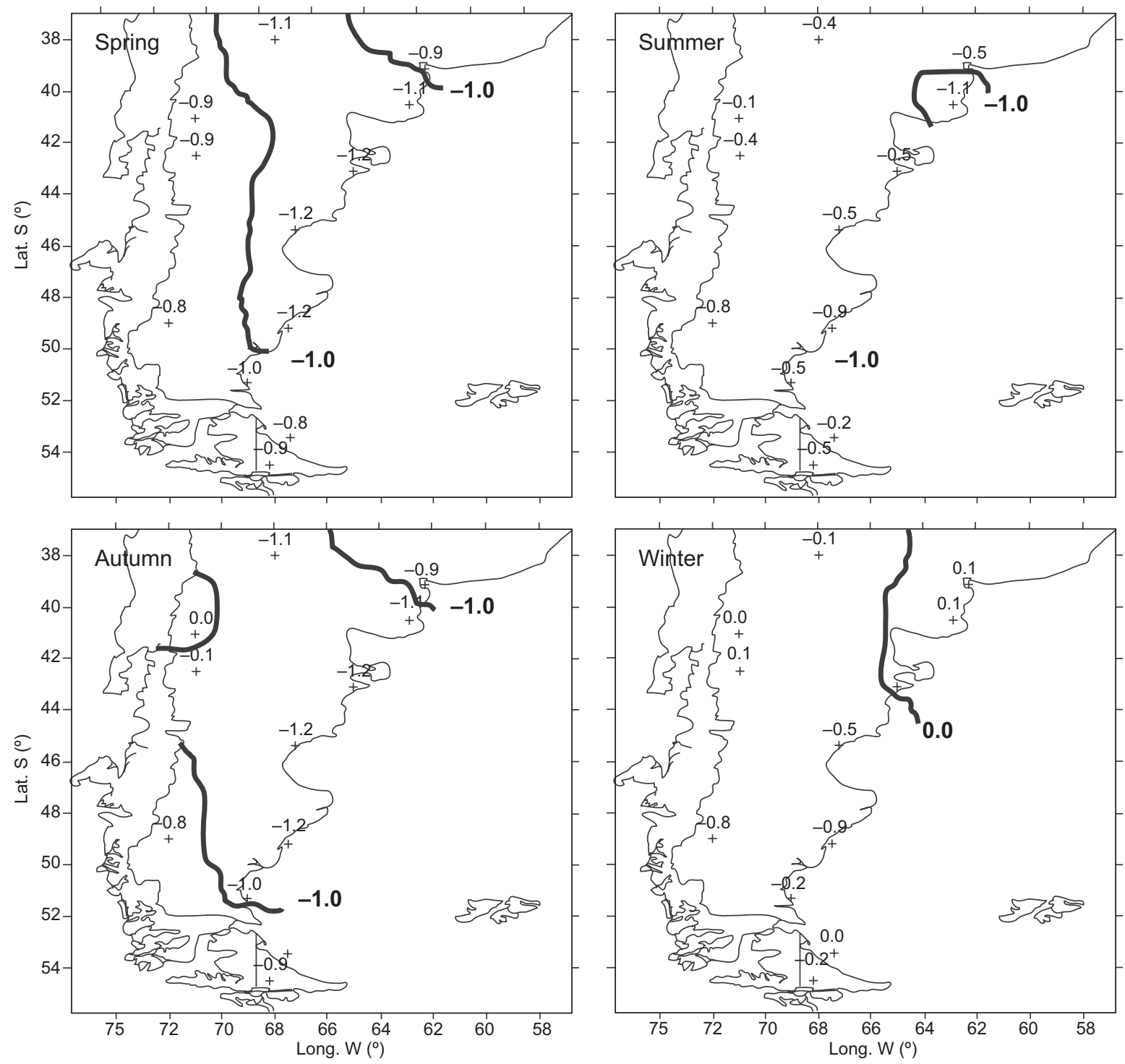

Fig. 7. Seasonal anomalies of temperature fields for B100. 

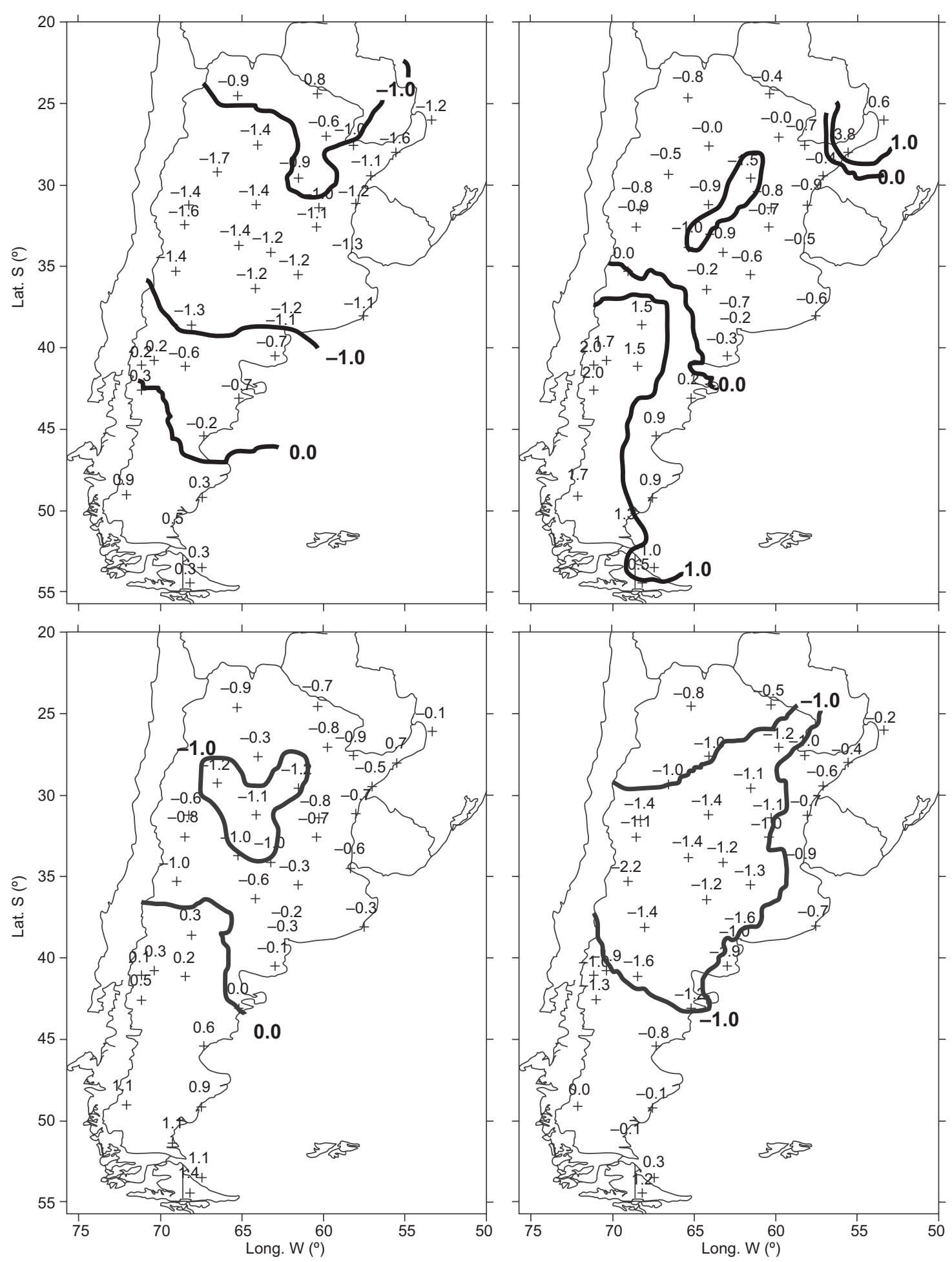

Fig. 8. Seasonal anomalies of temperature fields for B70. 


\subsubsection{Temperature}

According to the existing correlation between the indices and temperature mentioned in the introduction, the $\Delta \mathrm{T}$ fields resulted from the influence of blocking actions that are produced at $40^{\circ} \mathrm{W}$ just north of $38^{\circ}$ $\mathrm{S}$, are represented. These same fields are calculated throughout Argentina for B70 and only south of $38^{\circ}$ $\mathrm{S}$ of the country for B100.

Over the narrow land corresponding to Patagonia, which extends between the Atlantic and Pacific oceans, the predominant mean winds are from the SW. These are strong and intense. They are also very cold since they come from higher latitudes. This characteristic strengthens with the prevailing southern circulation caused by blockings at 100 and $70^{\circ} \mathrm{W}$ depending on the position.

The $\Delta \mathrm{T}$ values in Patagonia for B100 (Fig. 7) are predominantly negative, and this is especially true in spring and autumn. In the fields that corresponded to B100 (Fig. 4), according to the resulting anomalies,
Patagonia is affected at $1000 \mathrm{hPa}$ by a circulation from the south, particularly in spring and autumn. At $500 \mathrm{hPa}$ (Fig. 4), a great negative anomaly with a NW-SE direction is observed, which contributes to the intensification of the circulation from the southwest.

In spring and especially in winter, the temperature anomalies associated with B70 (Fig. 8) are the most negative. In spring and south of approximately $45^{\circ} \mathrm{S}$, however, the anomalies are positive. The anomalies are also positive at approximately south of $38^{\circ} \mathrm{S}$ in summer and autumn.

According to the mean fields of the geopotential heights corresponding to B70 (Fig. 5), in summer and autumn at $1000 \mathrm{hPa}$, a positive anomaly is observed to extend more to the north. On its way from north to south, the air flow adds a higher temperature, which explains why the cold flow from the south Atlantic could also reach lower latitudes and inhibit the northern flow at $1000 \mathrm{hPa}$, which could make a temperature increase possible.
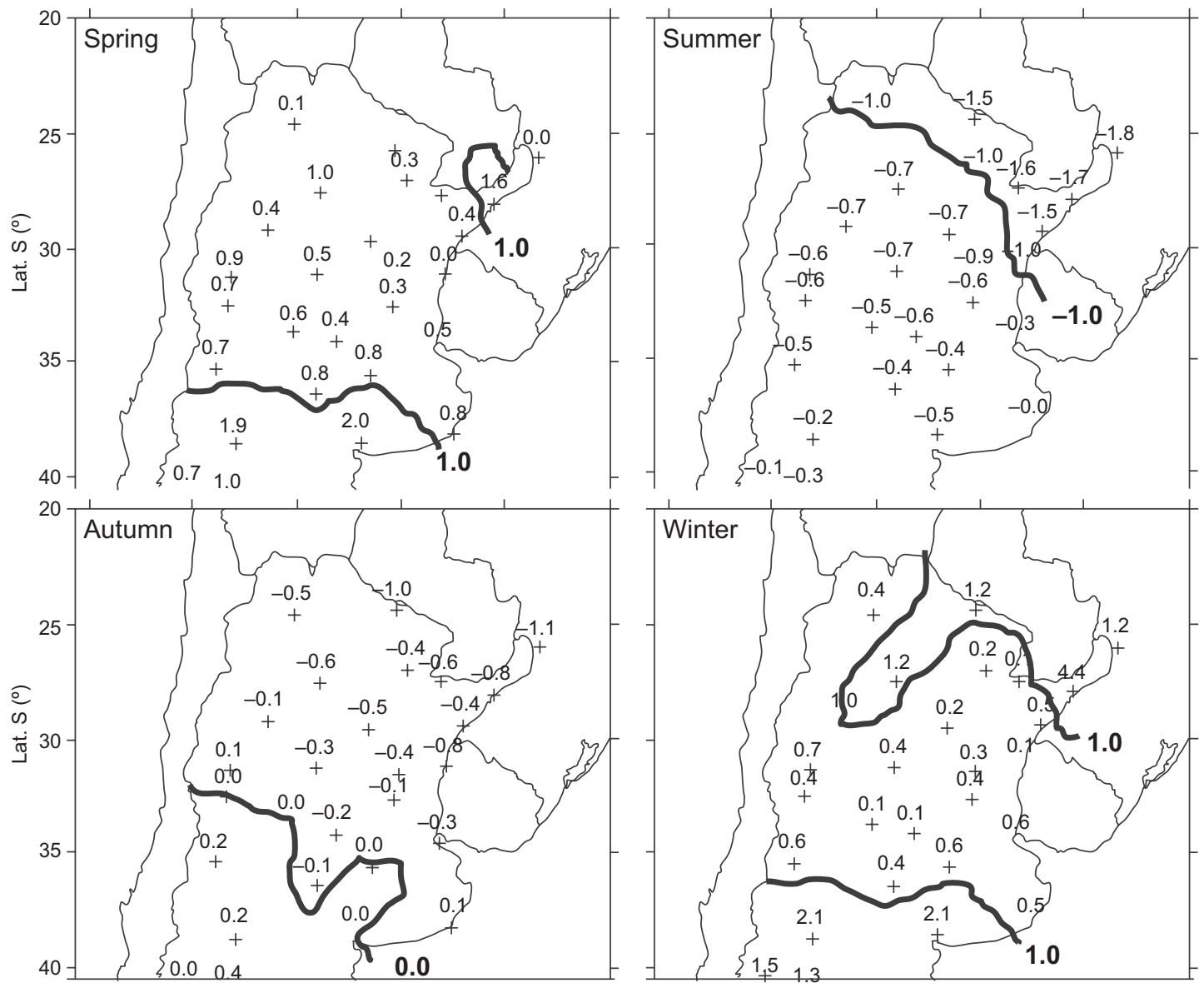

Fig. 9. Seasonal anomalies of temperature fields for B40. 
In Patagonia, the anomaly which causes temperature to decrease in winter presents a SE direction; the temperature increases when this flow comes from the $\mathrm{NE}$ or $\mathrm{E}$ in autumn, summer and spring. However, according to the non-significance of the correlation in the south of Patagonia previously mentioned in the Introduction, the signs of $\Delta \mathrm{T}$ would become unimportant.

At $500 \mathrm{hPa}$ (Fig. 5), the center of the anomaly associated with $1000 \mathrm{hPa}$ is located slightly to the west, where it reinforces the circulation from the Atlantic. However, at this level, a negative anomaly is observed north of $35-40^{\circ} \mathrm{S}$, which would indicate the greater frequency or predominance of trough passages or depression systems that can inhibit the development of high temperatures as a function of greater cloud cover, especially in spring and winter.

Figure 9 shows the anomalies in the four seasons for B40. Winter and spring show negative values. The winter contains more negative values, especially in the NE of the country, while in summer and autumn, the signs are positive. Figure 6 shows that at $1000 \mathrm{hPa}$, normal conditions north of $40^{\circ} \mathrm{S}$ are observed in the country. Even at $500 \mathrm{hPa}$ (Fig. 6), a negative anomaly is observed in the NE that could be due to a greater passage of fronts in that region that were forced by the position of B40. This anomaly is more intense and
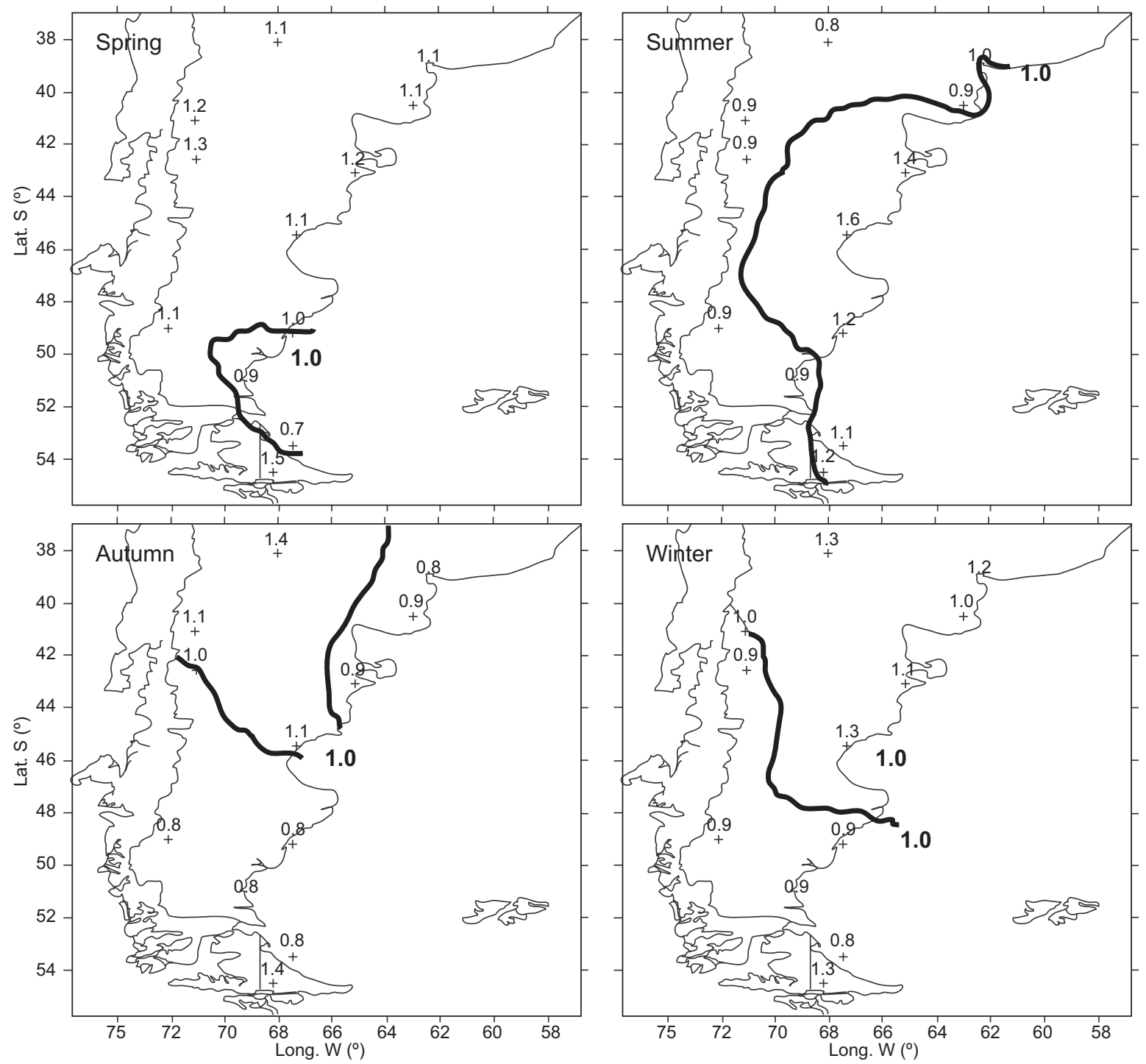

Fig. 10. Cumulative seasonal rainfall relationship R1 fields for B100. 

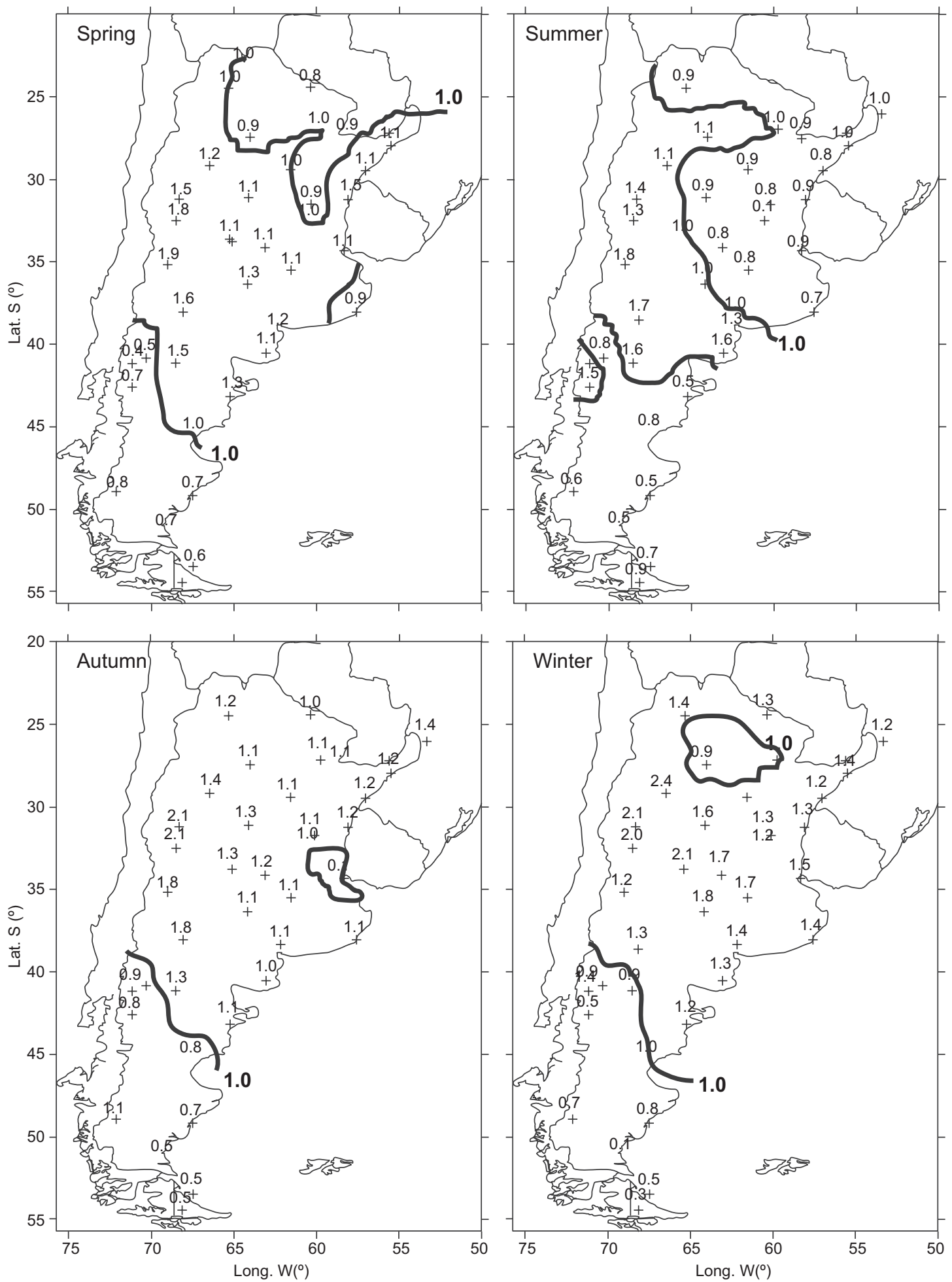

Fig. 11. Cumulative seasonal rainfall relationship R1 fields for B70.

extended to the west in winter and spring; the lesser extension of the same anomaly could be the cause for the higher temperature in summer and autumn.
At the 95\% level, the application of Student's $t$-test determined that the resultant $\Delta \mathrm{T}$ from $\mathrm{B}$ produced at $70^{\circ} \mathrm{W}$ are significantly different from those that 

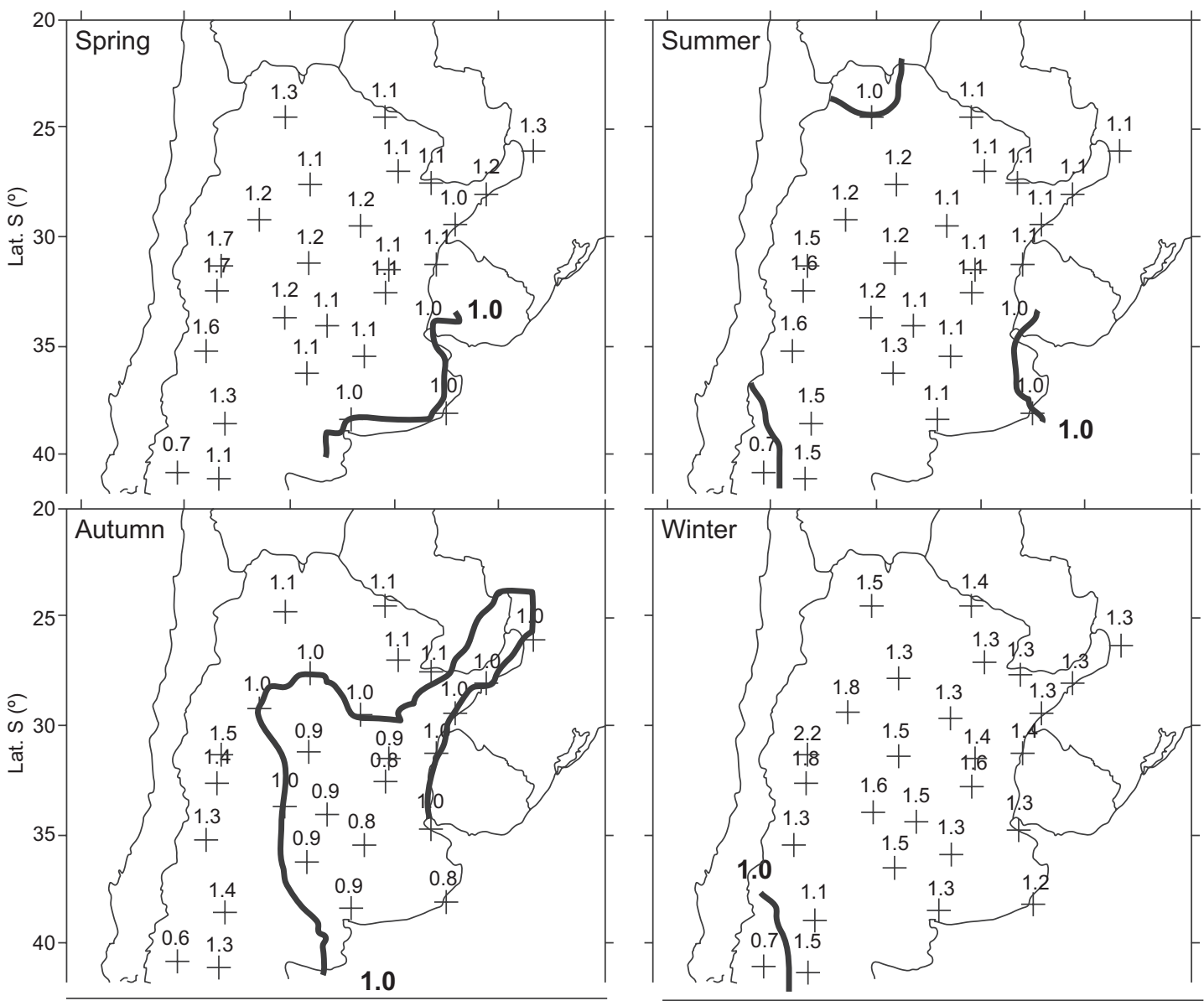

Fig. 12. Cumulative seasonal rainfall relationship R1 fields for B40.

correspond to the rest of the days in almost all the selected area in winter, spring and summer; this is also true for autumn and spring for B100. For B40 this test does not detect any significant differences at this level (see Annex 2). This result differs from the short period that was analyzed previously, where in most of the selected points, the annual values of $\Delta \mathrm{T}$ were significant.

\subsubsection{Precipitation}

The R1 precipitation relations caused by B100, B70 and B40 are presented in Figures 10-12. South of $38^{\circ} \mathrm{S}$, the relations that are caused by B100 (Fig. 10) show the greatest territorial extension with R1 $>1$ in spring, while in summer this condition is reduced to the east coast. In winter and autumn, the deficit values extended to the south of the diagonal, extending from approximately $41^{\circ} \mathrm{S}, 73^{\circ} \mathrm{W}$ to $49^{\circ} \mathrm{S}$, $65^{\circ} \mathrm{W}$. According to the $1000 \mathrm{hPa}$ fields for B100 (Fig. 4), the positive anomaly in the south Pacific is associated with a lack of precipitation in the south of Patagonia (Fig. 10), while precipitation to the north of this region is associated with the negative anomalies at $500 \mathrm{hPa}$ (Fig. 4) that extend diagonally from NW to SE between the Pacific and the Atlantic oceans, except during summer when they are located to the east of the country and do not seem to be connected to the anomaly in the Pacific.

R1 fields corresponding to B70 (Fig. 11) and B40 (Fig. 12), with the exception of summer, show a relative increase of accumulated precipitation in practically all of the selected stations north of $38^{\circ} \mathrm{S}$. In B70 during winter, values of R1 increase from 10 up to $140 \%$ in the center and north of the country. At $40^{\circ} \mathrm{W}$ for the same season, a similar field can be seen, but containing smaller values and with a maximum increase of $120 \%$.

In summer at both longitudes, the lowest accumulated precipitation values are observed in Buenos Aires, and in central and eastern Argentina. 
According to Figure 5, at $1000 \mathrm{hPa}$ there is a contribution of moisture from the Atlantic over the coastal areas of Argentina in all four seasons of the year. In winter and spring, the conditions north of $35^{\circ}$ are normal; in other words, the anticyclone of the Atlantic should contribute, according to its position (Minetti and Vargas, 1983), with the normal amounts of moisture for that time of the year.

However in autumn and especially in summer, when the influence of the negative anomaly reaches further north and the anticyclone of the Atlantic is further south, the moisture flow from the E or NE decreases, which causes a decrease in precipitation. At $500 \mathrm{hPa}$ in all four seasons, a negative anomaly is observed north of $38^{\circ} \mathrm{S}$. This anomaly is more intense and extensive in winter and spring, and is non-existent in summer in the region where the precipitation ratios are less than one.
In the south of the country, the rain is scarce as a consequence of the positive anomaly in both levels.

According to the B40 fields at $1000 \mathrm{hPa}$ (Fig. 6), there is a contribution of moisture over the coast of the country. Regarding this moisture contribution, a lesser extent during autumn and summer is observed. At $500 \mathrm{hPa}$, a negative anomaly similar to the one in B70 can be seen. This anomaly extends slightly over the east of Argentina in summer and autumn, and is associated with decreased precipitation during these seasons.

With respect to the R2 fields (not shown), values are similar to the R1 values for B70 and B100. However, for $\mathrm{B}$ produced at $40^{\circ} \mathrm{W}$, some differences are observed in the north of the country and in its surroundings, since few rainstorms are observed but a greater amount of precipitation is accumulated.
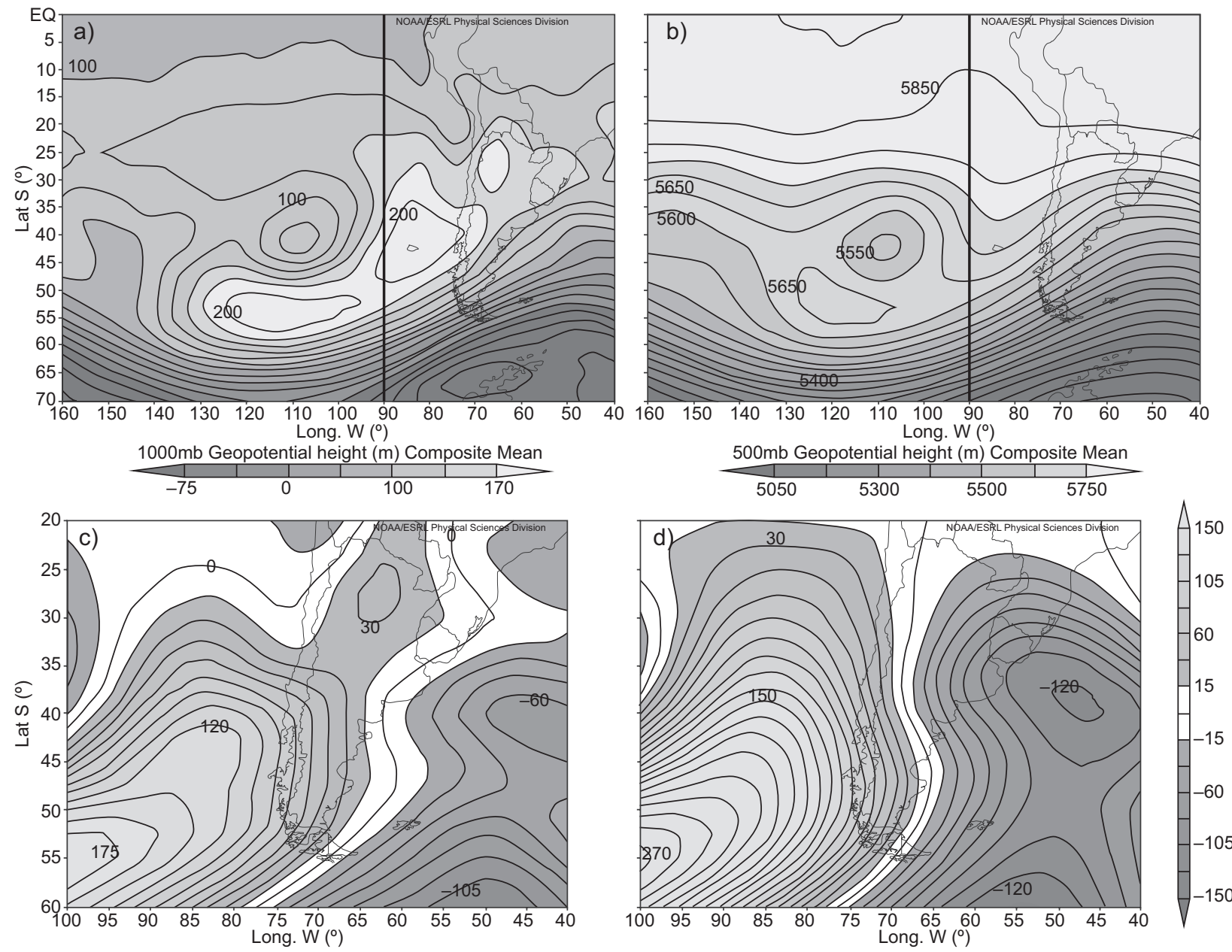

Fig. 13. (a, b) Mean 1000 and 500 hPa geopotential fields for the period June 2-9, 2012; (c, d) Same than (a, b), but for the anomalies of geopotential heights. 


\subsubsection{Blocking situation that took place between} June 2 and 10, 2012

A synthesis of the blocking situation that took place between June 2 and 10, 2012 is presented to characterize the consequences of such events. On May 27 at 500 $\mathrm{hPa}(\mathrm{R} 0)$ a ridge is observed over the Pacific Ocean at $160^{\circ} \mathrm{W}$ between $40-50^{\circ} \mathrm{S}$, with its corresponding high at $1000 \mathrm{hPa}(\mathrm{H} 0)$. During the following days, between May 28 and 31, both the ridge and high are positioned at $140^{\circ} \mathrm{W}$, while on June 1 it has moved to $120^{\circ} \mathrm{W}$.

On May 29 the Pacific subtropical High (H1) starts spreading south, intensifies and a low pressure system (L0) starts to segregate at $110^{\circ} \mathrm{W}, 45^{\circ}$ $\mathrm{S}$; located between $\mathrm{H} 1$ and $\mathrm{H} 0$; both high pressure systems associate (H2) affecting an extensive region which reaches up to $80^{\circ} \mathrm{W}$ in the following days, and continues to extend to $40^{\circ} \mathrm{W}$ on June 10 . It is considered that the blocking situation starts on June 2 when L0 is completely segregated. It remains north of the subpolar belt (approximately north of $45^{\circ} \mathrm{S}$ ) and in the Pacific Ocean until June 11. On this day it associates with a second low (L1) in the south Atlantic $\left(60^{\circ} \mathrm{S}, 40^{\circ} \mathrm{W}\right)$ and since $\mathrm{H} 2$ has retracted, the flow becomes more zonal, and pres- sure in southern Argentina descends. The blocking episode ends on June 10 when part of L1 crosses the continent. On June 11 a low-pressure system (L2) is located at $160^{\circ} \mathrm{W}$ the position previously occupied by R0 on May 27.

On June 13 H2 moves northeastwards and on June 14 segregates L1, which deviates north over the Pacific $\left(25-30^{\circ} \mathrm{S}\right)$ where it remains until June 18. Between these dates a new less intense blocking episode takes place.

The greatest extension of lowest $\mathrm{T}_{\min }$ values are observed on June 8 and 9 while the most negative values were reported on June 7, except in Patagonia

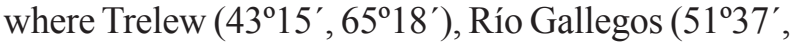
$\left.69^{\circ} 13^{\prime}\right)$ and Comodoro Rivadavia $\left(45^{\circ} 47^{\prime}, 67^{\circ} 30^{\prime}\right)$ reported lower temperatures on the following days.

The mean 500 and $1000 \mathrm{hPa}$ geopotential fields for the period June 2-9 2012 are presented in Figure 13a, b, respectively, while their corresponding anomalies are shown in Figure 13c, d. The predominant SW and S flows can be observed coming from $\mathrm{H} 2$, which caused the temperature decrease over Argentina. This is one of the three configurations that blockings present or what is known as Rex blocking.
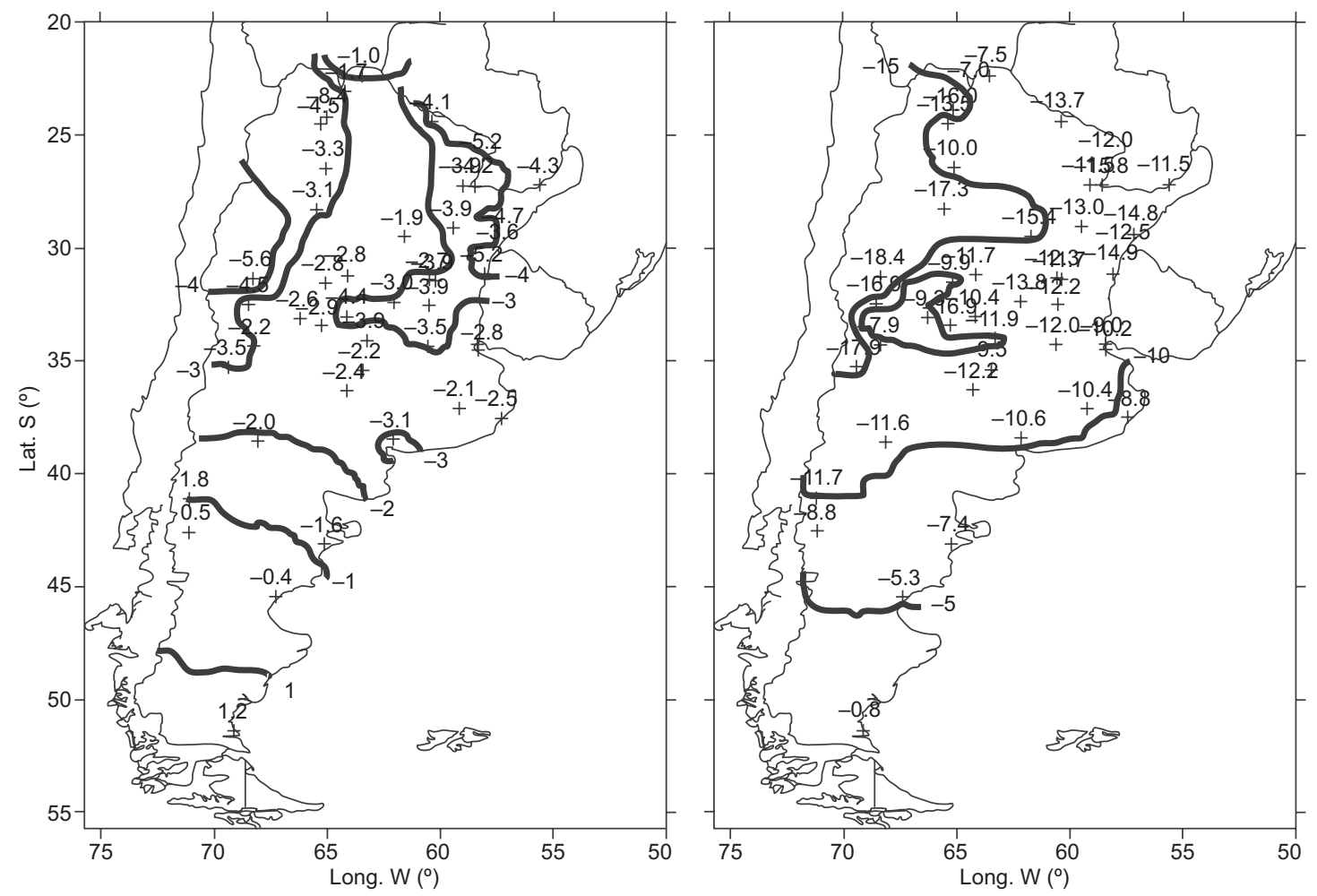

Fig. 14. (a) Mean anomalies of temperature fields for the period June 2-9, 2012; (b) Same than (a), but for the period June 5-9, 2012. 
The temperature anomalies observed during this period are plotted in Figure 14a indicating that, except in the extreme southeast, values are negative and significant over the rest of the country and strongest in the E and SE. Since the temperatures registered between June 5 and 9 are the lowest, Figure 14b shows the mean anomalies for this period, with negative values as low as $-8.4{ }^{\circ} \mathrm{C}$.

During this period precipitation was scarce since frontal systems were kept from passing by the blocking system. Only south of Santa Rosa $\left(36^{\circ} 37^{\prime}, 64^{\circ} 17^{\prime}\right)$

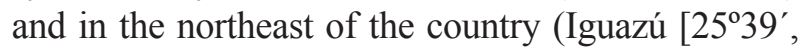
$\left.54^{\circ} 20^{\prime}\right]$ ) some rain was reported originated by moisture provided by the SW circulation in the first case and the east winds at $25^{\circ} \mathrm{S}$ in the second. In each case, however, the values were below their relative means.

\subsubsection{Estimated temperature and precipitation val-} ues according to results found in sections 2 and 3

The signs of the temporal trends of the Bs calculated in section 2 and the values of the temperature anomalies and R1 obtained in section 3 were taken into account. From the combination of these results, it is estimated that, in the 1960-2011 period, B70 may have contributed to an increase in the temperature north of $38^{\circ} \mathrm{S}$ in spring and to a decrease in summer and autumn. For example, if the trend equation of B70 in summer is positive, it indicates that blocking situations in summer increased during the selected period. Moreover, in this season the B70 determine negative temperature anomalies therefore the increase of B70 in summer might contribute to a decrease of temperature during the course of this period.

Even if the temperature anomalies are not significant at the $95 \%$ level for B40, in summer and autumn these factors could slightly contribute to the decrease of this variable.

South of $38^{\circ} \mathrm{S}$, with the exception of winter, B70 contributed to the temperature increase, while B100 contributed to its decrease in summer and increase in winter.

With respect to precipitation north of $38^{\circ} \mathrm{S}$, all the Bs could contribute to its diminution in summer, B70 and B40 in autumn and B100 in winter; however, B70 might favor the increase of precipitation during spring.

South of $38^{\circ}$ S, B70 and B100 would contribute to a precipitation decrease in summer, and B70 might contribute to this decrease in autumn, while B100 might contribute to a precipitation increase in winter, and B70 would favor a precipitation increase in spring.

\section{Conclusions}

The goal of this analysis is to determine the variability and temporal distribution of blocking actions (Bs) produced at 100,70 and $40^{\circ} \mathrm{W}$ during the period 1960-2011; the additional goals are to determine the influence of the Bs on seasonal values of temperature and precipitation and their seasonal trends, and to determine the influence that Bs could have on both variables during selected period. According to these objectives, the following points are concluded:

1. The Bs produced in the three longitudes are more frequent in spring and less frequent in summer, with a secondary maximum slightly smaller than the absolute maximum in winter.

2. The trends of blocking actions that are determined at 100,70 and $40^{\circ} \mathrm{W}$ show positive signs in summer and autumn. In the latter season, with the exception of autumn for B100, trends are significant. During spring and winter, the Bs show negative trends, but only significant for B100 in winter and for B70 in spring.

It is noteworthy that the Bs increase in the season of the year in which their occurrence is less frequent, and they decrease in those seasons with greater frequency. In summer, an increase of the Bs is observed in the last two decades.

3. According to the atmospheric circulation associated to the blocking situations produced at each of the selected longitudes, they determine, in general, a seasonal decrease in temperature and increase in precipitation over the Argentine territory.

3.1 Situations occurring at $100^{\circ} \mathrm{W}$ determine in all seasons below zero temperature anomalies $(\Delta \mathrm{T}$ $<0)$ south of $38^{\circ} \mathrm{S}$. B70 also produce negative anomalies in most of Argentina; nevertheless, the area is reduced during autumn and summer when positive anomalies are observed south of $38^{\circ} \mathrm{S}$.

- Although Student's t-test does not detect any significant differences for the temperature anomalies produced by B40, negative anomalies north of $38^{\circ} \mathrm{S}$ in winter are also produced by B40. During spring the negative anomalies are observed north of $35^{\circ} \mathrm{S}$, however, during autumn and summer they are positive. 
3.2 B70s cause above normal seasonal precipitations (R1 > 1) over all of Argentina. B40s, however, only cause R1 $>1$ north of $38^{\circ} \mathrm{S}$, except in summer where the area is restricted to the west coast. R1 values $>1$ caused by $\mathrm{B} 100$ are found south of $38^{\circ} \mathrm{S}$ during spring, in the coastal area during summer and north of the NW-SE diagonal between 41 and $49^{\circ} \mathrm{S}$ in winter and autumn.

- When B is calculated at 70 and $100^{\circ} \mathrm{W}$, the frequencies of days of seasonal precipitation evaluated with R2 mostly coincide with R1 fields, however for $40^{\circ} \mathrm{W}$, differences are observed between these values. In other words, the greater accumulated precipitations display lower frequencies and vice versa.

$\mathrm{B} 100$ s have the strongest influence over temperature and precipitation in Patagonia.

4. According to the statistical values of the temperature and precipitation that are determined by the Bs and the signs and significance of the seasonal trends of these, it is estimated for the period 1960-2011 that Bs could contribute in the following way:

- North of the NW-SE diagonal approximately from 38 to $43^{\circ} \mathrm{S}$ :

- B70 and to a lesser degree B40 could cause a temperature increase in spring and a decrease in summer and autumn.

- B70 and B40 could determine an increase in autumn precipitation, and B70 might determine a decrease in spring.

- South of the diagonal:

- B70 could produce an increase in temperature, except in winter, while B100 might produce a decrease in summer and an increase in winter.

- B70 could contribute to a decrease of precipitation in summer and autumn and to an increase in spring, while B100 could contribute to an increase in winter.

\section{Acknowledgments}

This study was supported by grant 228 of the Universidad de Buenos Aires (UBA).

\section{References}

Alessandro A. P., 2003a. Blocking action situations in the south of South America during the 1990s. Meteorologica 28, 23-38.
Alessandro A. P., 2003b. Influence of blocking on temperature and precipitation in Argentina during the 90's decade. Meterologica 28, 39-52.

Alessandro A. P., 2005a. Acciones bloqueantes alrededor de los setenta grados oeste en el Sur de Sudamérica. Meteorologica 30, 3-23.

Alessandro A. P., 2005b. Bloqueos simultáneos en el Atlántico y Pacífico Sur y sus influencias sobre la República Argentina. Revista Brasileira de Meteorologia 20, 277-300.

Alessandro A. P., 2011. Relationship between values and trends of two circulation indices and temperature and rainfall in Argentina. Meteorol. Appl., doi:10.1002/ met.274.

Berbery E. H. and A. Lozano, 1991. Características regionales de anomalías persistentes de alturas en los océanos Atlántico y Pacífico Sur. Anales de VI Congremet, 153-154.

Brooks C. E. and N. Carruthers, 1953. Handbook of statistical methods in meteorology. Madison, USA, 412 pp.

Kayano M. T. and V. E. Kousky, 1989. Hemispheric blocking climatology. Third International Conference on Southern Hemisphere Meteorology and Oceanography, Buenos Aires, Argentina, 132-133.

Kayano M. T., 1999. Southeastern Pacific blocking episodes and their effects on the South American weather. Meteorol. Atmos. Phys. 69, 145-155.

Kidson J. W., 1986. Index cycles in the Southern Hemisphere during the Global Weather Experiment. Mon. Weather Rev. 114, 1654-1663.

Kiladis G. N. and K. Mo, 1998. Interannual and intraseasonal variability in the Southern Hemisphere. In: Meteorology of the Southern Hemisphere (D. J. Karoly and D. G. Vincent, Eds.). American Meteorological Society, Boston, 307-336.

Kreienkamp F., A. Spekat and W. Enke, 2010. Stationarity of atmospheric waves and blocking over Europebased on a reanalysis dataset and two climate scenarios. Theor. Appl. Climatol. 102, 205-212.

Lejenas H. and H. Okland, 1983. Characteristics of northern blocking as determined from a long time series of observational data. Tellus A 35, 350-362.

Lejenas H, 1984. Characteristics of Southern Hemisphere blockings determined from a long time series of observational data. Q. J. Roy. Meteor. Soc. 110, 960-979.

Marques R. F. C. and V. B. Rao, 1999. A diagnosis of a long-lasting blocking event over the southeast Pacific Ocean. Mon. Weather Rev. 127, 1761-1775. 
Minetti J. L. and W. M. Vargas, 1983. Comportamiento del borde anticiclónico subtropical en Sudamérica. Parte I. Meteorologica 14, 645-655.

Mo K., 1983. Persistent anomalies of the Southern Hemisphere circulation. Proceedings of the First International Conference on Southern Hemisphere Meteorology, Brazil. American Meteorological Society, 70-72.

Mo K. and R. W. Higgins, 1997. Planetary waves in Southern Hemisphere and linkage to the tropics. NCAR Tech. Note TN-433+PROC, 287 pp.

Noar P., 1983. Numerical modeling of blocking with reference to June 1982. Aust. Meteorol. Mag. 31, 37-49.

Rex D. F., 1950. Blocking action in the middle troposphere and its effect upon regional climate. Tellus 2, 275-301, doi:10.1111/j.2153-3490.1950.tb00339.x.

Rutllant J. H. and H. Fuenzalida, 1991. Synoptic aspects of the central Chile rainfall variability associated with the Southern Oscillation. J. Climatol. 11, 63-76.

Sinclar M. R., 1996. A climatology of anticyclones and blocking for the Southern Hemisphere. Mon. Weather Rev. 16, 245-263.
Taljard J., 1972. Synoptic meteorology of the Southern Hemisphere. Meteorology of the Southern Hemisphere. Meteor. Mon. 35, 139-211.

Tibaldi S., E. Tosi, A. Navarra and L. Pedulli, 1994. Northern and Southern Hemisphere seasonal variability of blocking frequency and predictability. Mon. Weather Rev. 122, 1971-2003.

Trenberth K. and E. G. S. Swanson, 1983. Blocking and persistent anomalies in the Southern Hemisphere. Proceedings of the First International Conference on Southern Hemisphere Meteorology. American Meteorological Society. San José Dos Campos, Brazil.

Trenberth K. E. and K. Mo, 1985. Blocking in the Southern Hemisphere. Mon. Weather Rev. 113, 2-21.

Trenberth K. E., 1986. The signature of a blocking episode on the general circulation in the Southern Hemisphere. J. Atmos. Sci. 43, 2061-2069.

Van Loon H., 1956. Blocking action in the Southern Hemisphere. Part I. Notos 5, 171-177. 


\section{Annex 1}

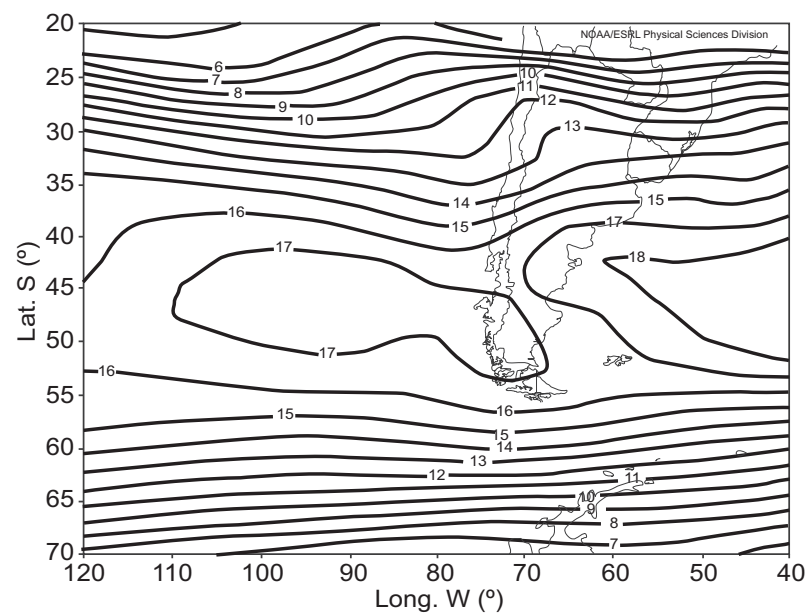

$500 \mathrm{hPa}$ mean annual zonal wind (m/s) for 1968-2000. Source: NCEP/NCAR reanalysis. 


\section{Annex 2}

Two tail Student's t-statistic $(\mathrm{T})$, at significance level $=0.05$.

\begin{tabular}{|c|c|c|c|c|c|c|c|c|c|c|c|c|}
\hline \multirow{2}{*}{$\begin{array}{l}\text { Meteorological stations } \\
\text { (lat. S, long. W }\left[^{\circ}\right] \text { ) }\end{array}$} & \multicolumn{4}{|c|}{$100^{\circ} \mathrm{W}$} & \multicolumn{4}{|c|}{$70^{\circ} \mathrm{W}$} & \multicolumn{4}{|c|}{$40^{\circ} \mathrm{W}$} \\
\hline & Sp. & $\mathrm{Su}$. & $\mathrm{Au}$. & Wi. & Sp. & Su. & Au. & Wi. & Sp. & $\mathrm{Su}$. & Au. & Wi. \\
\hline Las Lomitas $(24,42 ; 60,35)$ & * & $*$ & * & * & 1.7 & -8.9 & 3.4 & -1.9 & -1.1 & 2.5 & -2.1 & 1.9 \\
\hline Iguazú $(25,44 ; 54,28)$ & * & * & $*$ & * & -4.4 & -8.2 & 8.8 & -1.2 & -2.1 & 1.8 & -2.1 & 1.2 \\
\hline Posadas $(27,22 ; 55,58)$ & * & $*$ & * & * & -4.6 & -4.2 & 8.9 & -2.2 & -2.6 & 2.6 & -1.1 & 1.1 \\
\hline P. de los Libres $(29,41 ; 57,09)$ & * & * & $*$ & * & -3.2 & -4.5 & -8.2 & -4.5 & -2.6 & 1.1 & -1.5 & 2.1 \\
\hline Mte. Caseros $(30,16 ; 57,37)$ & $*$ & * & $*$ & * & -3.3 & -6.8 & -4.2 & -1.8 & -1.1 & 2.2 & -1.2 & 2.1 \\
\hline Concordia $(31,18 ; 57,37)$ & * & * & $*$ & * & -5.3 & -3.5 & -4.5 & -3.5 & -2.2 & 1.2 & -2.2 & 2.1 \\
\hline Reconquista $(29,11 ; 59,42)$ & $*$ & * & $*$ & $*$ & -5.8 & -7.9 & -6.8 & 1.8 & -0.8 & 0.8 & -0.5 & 1.1 \\
\hline Ceres $(29,53 ; 61,57)$ & $*$ & * & $*$ & * & -8.5 & -4.2 & -7.2 & -3.5 & -1.2 & 0.2 & -1.6 & 0.7 \\
\hline alta $(24,51 ; 65,29)$ & $*$ & * & $*$ & * & -2.6 & -8.5 & -7.2 & -2.6 & -2.2 & 1.5 & -1.2 & 1.6 \\
\hline 9,$23 ; 66,49)$ & $*$ & $*$ & $*$ & $*$ & -6.6 & -2.6 & -4.2 & -1.2 & -1.9 & 1.5 & -2.2 & 2.1 \\
\hline 27,46 & $*$ & $*$ & $*$ & $*$ & -9.2 & -5.3 & -8.2 & -4.2 & -1.2 & 2.1 & -1.2 & 1.1 \\
\hline 08 & $*$ & $*$ & $*$ & $*$ & -5.9 & -7.2 & -4.2 & -1.2 & -1.9 & 1.9 & -1.1 & 2.6 \\
\hline [. J & * & * & $*$ & $*$ & -8 & -4.2 & -12 & -4.2 & -1.2 & 1.2 & -1.2 & 2.1 \\
\hline 2,$38 ; 02,41$ & $*$ & $*$ & $*$ & $*$ & -7.6 & -3.3 & -3.2 & -1.3 & -2.5 & 2.1 & -1.2 & 1.8 \\
\hline 1) & $*$ & $*$ & $*$ & $*$ & -3.9 & -8.2 & -6.3 & -7 & -1.8 & 1.1 & -1.5 & 2.2 \\
\hline an Luis ( & $*$ & $*$ & $*$ & $*$ & -6.5 & -4.2 & -8.3 & -5.3 & 1.5 & 0.6 & -2.2 & .6 \\
\hline 2,$53 ; 68,51)$ & $*$ & $*$ & $*$ & $*$ & -1.9 & -1.1 & -10 & -8.9 & 0.9 & 1.5 & -2.2 & 1.9 \\
\hline 5,$3 ; 69,35)$ & $*$ & $*$ & $*$ & $*$ & -8.9 & -1.7 & -6.3 & -6.8 & 2.1 & 0.9 & -1.8 & 1.1 \\
\hline sa $(36,34 ; 64,16)$ & $*$ & $*$ & $*$ & $*$ & -8.2 & -3.3 & -3.3 & -3.3 & -1.1 & 1.1 & -2.2 & 0.2 \\
\hline$(31,47 ; 60,29)$ & $*$ & $*$ & $*$ & $*$ & -4.2 & -3 & -8.5 & -3 & -0.6 & 2.1 & -2 & 1.5 \\
\hline$(32,55 ; 60,47)$ & $*$ & $*$ & $*$ & $*$ & -4.5 & -8.9 & -2.6 & -1.1 & -1.5 & 2.6 & 1.9 & 1.5 \\
\hline Cnel. Suárez $(37,26 ; 61$ & * & $*$ & $*$ & * & -6.8 & -4.5 & -5.3 & -1.1 & -2.1 & 2.2 & -2.2 & 2.1 \\
\hline Ezeiza $(34,49 ; 58,32)$ & * & $*$ & * & * & -7.2 & -9 & -5.8 & -4.5 & -0.2 & 1.9 & -1.2 & 2.5 \\
\hline M. del Plata $(37,56 ; 57$, & * & * & * & * & -4.2 & -1.9 & -6.6 & -1.9 & -1.5 & 1.2 & -1.1 & 1.8 \\
\hline Maquinchao $(41,15 ; 68,44)$ & * & * & * & * & -9 & 3.8 & -7.9 & 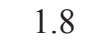 & 2.0 & 1.9 & -1.9 & 0.8 \\
\hline B. Blanca $(38,44 ; 62,1)$ & -3.2 & -1.3 & 1.3 & -3.5 & -3.3 & -6.8 & -9.2 & -1.7 & 1.2 & 1.3 & -1.5 & 0.9 \\
\hline$(38,57 ; 68,08)$ & -3.3 & -4.8 & 3.1 & -2.6 & -3 & 6 & -3.5 & 6 & 1.1 & 2 & -2.2 & 2.2 \\
\hline Bariloche $(41,09 ; 71,1)$ & -3.2 & -4.5 & -2.1 & -3.2 & 8 & 9.5 & -4.2 & 0.5 & 1.6 & 1.8 & -2.1 & -1.3 \\
\hline Esquel $(42,56 ; 71,09)$ & -4.9 & -1.2 & 1.8 & -2.2 & 8.2 & 6.4 & -7.7 & 3.5 & $*$ & $*$ & $*$ & * \\
\hline Trelew $(43,12 ; 65,16)$ & -8 & -1.3 & -1.2 & -4.2 & 7.1 & 2.8 & -5.6 & 2.8 & $*$ & $*$ & $*$ & * \\
\hline C. Rivadavia $(45,47 ; 67,3$ & -2.6 & -2.5 & -2.2 & -1.9 & $-\mathbf{3}$ & 7.1 & -1.6 & 4.5 & $*$ & $*$ & $*$ & * \\
\hline S. Julián $(49,19 ; 67,47)$ & -3.2 & -1.3 & -2.4 & -3.9 & 3.5 & 12 & -3 & 1.1 & $*$ & $*$ & $*$ & * \\
\hline L. Argentino $(50,2 ; 72,18)$ & -4.3 & -3.2 & -0.1 & -3.2 & 0.9 & 8.3 & 8 & 8.3 & $*$ & $*$ & $*$ & * \\
\hline R. Grande $(53,48 ; 67,45)$ & -4.8 & -1.5 & 3.1 & -4.2 & 1.8 & 4.5 & 6.3 & 1.1 & $*$ & * & $*$ & $*$ \\
\hline Usuahia $(54,48 ; 68,19)$ & -3.5 & -2.6 & 1.6 & -1.2 & 2 & 2.1 & 2.1 & 1.8 & $*$ & $*$ & $*$ & * \\
\hline P. Madrim $(42,47 ; 65,01)$ & -8 & -2.3 & 3.1 & -2.2 & -2.1 & 2.5 & 1.9 & 2 & $*$ & $*$ & $*$ & * \\
\hline Viedma $(40,51 ; 63,01)$ & -2.6 & -0.5 & 2.3 & -3.3 & -1.9 & 2.1 & -1.3 & 1.7 & * & $*$ & $*$ & * \\
\hline R. Gallegos $(51,37 ; 69,17)$ & -3.9 & -1.2 & -1.3 & -2.6 & 1.9 & 3 & 4 & -1.1 & $*$ & $*$ & $*$ & $*$ \\
\hline
\end{tabular}

Significant values are in bold. 